\title{
PENGARUH PERSEPSI NASABAH TENTANG PROMOSI DAN KUALITAS PELAYANAN TERHADAP MINAT MENABUNG NASABAH
}

(Studi Kasus Pada Bank BJB syariah Kantor Cabang Pembantu Cikarang, Bekasi)

\author{
Sakum \\ Hidaya Iftia \\ STAI PELITA BANGSA \\ mr.sakum@yahoo.co.id
}

\begin{abstract}
ABSTRAK
Tujuan dari penelitian ini adalah untuk mencari adakah pengaruh antara persepsi nasabah tentang promosi dan kualitas pelayanan secara parsial terhadap minat menabung, di BJB syariah. Tujuan yang kedua adalah untuk mengetahui adakah pengaruh antara persepsi nasabah tentang promosi dan kualitas pelayanan secara simultan terhadap minat menabung di BJB syariah. Hasil penelitian menunjukkan bahwa ada pengaruh antara persepsi nasabah tentang promosi dan kualitas pelayanan secara parsial maupun simultan terhadap minat menabung di BJB. Kualitas pelayanan, dalam penelitian ini, lebih mempengaruhi minat menabung dari pada persepsi nasabah tentang promosi.
\end{abstract}

Kata kunci: Persepsi nasabah; promosi; kualitas pelayanan; minat menabung.

ABSTRACT

The purpose of this study is to find whether there is influence between customer perceptions about promotion and quality of service partially to interest in saving, in BJB sharia. The second goal is to know whether there is influence between customer perception about promotion and quality of service simultaneously to interest of saving in BJB syariah. The result of research indicate that there is influence between customer perception about promotion and service quality partially and simultaneously to the saving intention in BJB. Quality of service, in this study, influence the interest of saving more than on the customer's perception of promotion.

Key words: Customers' perception; promotion; service quality; saving intention.

\section{PENDAHULUAN}

Beberapa dekade belakangan ini industri perbankan terus berkembang dengan pesatnya, sehingga sektor ini menjadi sektor andalan dalam perkembangan perekonomian daerah maupun nasional. Sektor perbankan itu sendiri merupakan salah satu dari sekian banyak sektor jasa yang ada dan berkembang saat ini, dimana pengelolaan dan pengembangan industri perbankan sangat memerlukan strategi manajemen yang baik serta keterlibatan sumber daya manusia yang profesional. Bank merupakan suatu lembaga keuangan yang berperan penting 
dalam perekonomian suatu negara. Semakin berkembang industri perbankan maka semakin baik pula pertumbuhan ekonomi negara tersebut.

Dalam penilaian Global Islamic Financial Report (GIFR) Indonesia menduduki urutan keempat negara yang memiliki potensi dan kondusif dalam pengembangan industri keuangan syariah setelah Iran, Malaysia dan Saudi Arabia. Pengembangan tersebut sejalan dengan laju ekspansi kelembagaan dan akselerasi pertumbuhan aset perbankan syariah yang sangat tinggi.

Keunggulan struktur pengembangan keuangan syariah di Indonesia adalah regulatory regime yang dinilai lebih baik dibanding dengan negara lain. Di Indonesia kewenangan mengeluarkan fatwa keuangan syariah bersifat terpusat oleh Dewan Syariah Nasional (DSN), Majelis Ulama Indonesia (MUI) yang merupakan institusi yang independen. Sementara di negara lain, fatwa dapat dikeluarkan oleh perorangan ulama sehingga terjadinya perbedaan sangat besar. Di Malaysia, struktur organisasi fatwa ini berada di bawah Bank Negara Malaysia (BNM), dan berdiri sendiri secara independen . Perkembangan yang pesat dalam dunia perbankan saat ini ditandai dengan banyaknya bank syariah dan bank konvensional yang bermunculan, oleh sebab itu suatu bank harus lebih peka terhadap kebutuhan maupun perilaku nasabah agar tidak berpindah ke bank lain. Perilaku nasabah terhadap bank dapat dipengaruhi oleh sikap dan persepsi nasabah terhadap karakteristik perbankan itu sendiri . Dalam Persepsi nasabah ada yang mempersepsikan sesuatu itu baik atau positif dan negatif. Upaya untuk meningkatkan minat menabung nasabah tidak mudah begitu saja, ada tantang tersendiri untuk penilaian nasabah terhadap sesuatu yang ia terima dan rasakan terhadap apa yang diberikan perbankan. Untuk itu dalam upaya meningkatkan minat menabung nasabah diharapkan dapat memberikan yang terbaik agar persepsi nasabah positi khususnya persepsi nasabah tentang promosi dan kualitas pelayanan.

Bank bjb syariah KCP Cikarang memiliki langkah-langkah tertentu untuk meningkatkan minat menabung nasabah yaitu dengan mempromosikan produkproduk yang dimilikinya, termasuk Pulisitas (Public relation). Walaupun demikian masih banyak masyarakat yang belum paham betul dengan produk apa saja yang dimiliki perbankan syariah, masih banyak masyarakat yang masih awam dengan karakteristik perbankan syariah. Bank bjb syariah masih fokus dalam mempromosikan produknya ke sekolah-sekolah atau instansi lembaga pendidikan, kemudian yang jadi masalah kenapa tidak di perusahaan-perusahaan tertentu atau di buat iklan yang menarik khususnya kota Cikarang yang menjadi kota industri, dari hal tersebut memberikan persepsi atau sudut pandang yang berbeda mengenai promosi yang dilakukan bank bjb syariah KCP Cikarang yang beranggapan bahwa promosi hanya khusus untuk lembaga pendidikan padahal bukan demikian. Persepsi merupakan hasil proses seseorang memilih, mengatur dan menginpretasikan informasi sesuatu hal. Oleh sebab itu dalam membangun persepsi yang baik maka perlu adanya langkah perbankan yang bijak agar mudah diterima dengan nasabah agar tidak terjadi penilaian yang buruk tentang produk perbankan syariah yang khusus menerima dana di lembaga pendidikan saja 
padahal bank bjb syariah dalam menghimpun dana bebas dari pihak manapun asal ada kesepakatan yang sesuai syariat islam.

Perbankan syariah tidak mengenal adanya riba atau tambahan namun masih banyak masyarakat yang tertarik menggunakan produk-produk konvensional agar mendapat bunga yang berlebih. Persepsi nasabah dalam penilaian karakteristik bank konvensional dan syariah adalah sama padahal dalam lalu lintas keuangan bank konvensional ada tambahan riba sedangkan bank syariah adalah bagi hasil, hanya beberapa persen yang memahami akan hal ini. Firman Allah SWT menegaskan akan keharaman praktek riba yaitu sesuai firman Allah SWT.:

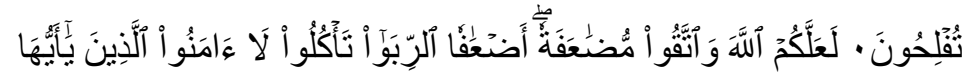

Hai orang-orang yang beriman, janganlah kamu memakan riba dengan berlipat ganda dan bertakwalah kamu kepada Allah supaya kamu mendapat keberuntungan. (QS.Ali Imran : 130).

Pelayanan yang diberikan bank bjb syariah kepada nasabah sudah cukup baik, dari customer service, taller, dan security yang bertugas memverifikasi kepentingan nasabah. Namun anggapan mengenai penilaian pelayanan yang diberikan perbankan belum cukup puas, hal ini terlihat dari bank bjb syariah memiliki peringkat ke 3 (tiga) dari beberapa kantor cabang di Bekasi, kemudian dalam penilaian kualitas pelayanan kenapa tidak mendapat pertama atau kedua. Hal ini mengindikasikan bahwa persepsi mengenai kualitas pelayanan masih kurang mendukung dari keinginan dan harapan nasabah. Dalam kaitannya untuk penilaian persepsi nasabah tentang kualitas pelayanan, masih banyak nasabah yang miss communication dengan petugas bank bjb syariah. Oleh sebab itu perlu adannya tambahan edukasi untuk memberikan persepsi yang baik mengenai kualitas pelayanan untuk menarik minat menabung.

Tujuan dari penelitian ini adalah untuk menjawab pertanyaan-pertanyaan berikut:

1. Adakah pengaruh persepsi nasabah tentang promosi terhadap minat menabung di BJB syariah?

2. Adalah pengaruh persepsi nasabah tentang kualitas pelayanan terhadap minat menabung di BJB syariah?

3. Adakah pengaruh persepsi nasabah tentang promosi dan kualitas pelayanan secara simultan terhadap minat menabung di BJB syariah?

\section{PERSEPSI NASABAH TENTANG PROMOSI, KUALITAS PELAYANAN, DAN MINAT MENABUNG}

Persepsi adalah proses dimana seseorang memilih, mengatur dan menginpretasikan informasi untuk membentuk suatu yang berarti mengenai dunia (Kotler, 2016). Faktor-faktor yang mempengaruhi persepsi seseorang adalah sebagai berikut (Ainamulyana, 2016):

1. Faktor internal : perasaan, sikap dan kepribadian individu, prasangka, keinginan atau harapan, perhatian (fokus), proses belajar, keadaan fisik, gangguan kejiwaan, nilai dan kebutuhan juga minat, dan motivasi. 
2. Faktor eksternal : latar belakang keluarga, informasi yang diperoleh, pengetahuan dan kebutuhan sekitar, intensitas, ukuran, keberlawanan, pengulangan gerak, hal-hal baru dan familiar atau ketidak asingan suatu objek.

Dari uraian diatas bahwa Persepsi adalah proses dimana seseorang memilih, mengatur dan menginpretasikan informasi. Dari persepsi Persepsi adalah proses seseorang atau pengorganisasian dari interpretasi dari stimulus yang diterima, baik berupa rangsangan atau informasi serta pesan yang diterima dan dirasakan oleh panca indera manusia. Persepsi bukan hanya sebatas pada penginderaan terhadap objek atau lingkungan saja tetapi lebih luas. Seseorang dapat memberikan penilaian dan pandangan atau pendapat yang berbeda terhadap suatu objek walapun kita melihat dengan benda yang sama. Persepsi seseorang dapat berubahubah, misalnya baik menjadi buruk atau sebaliknya.

\section{Persepsi Nasabah}

Dalam dunia perbankan yang dimaksud dengan konsumen atau pelanggan adalah nasabah. Nasabah adalah pihak yang menggunakan jasa bank syariah dan atau Unit Usaha Syariah (Syamsuriza, 2012). Nasabah merupakan aset suatu perbankan untuk meningkatkan perkembangan perusahaan tersebut, semakin banyak nasabah yang bertransaksi dalam keuangan maka semakin cepat pula pertumbuhan perekonomian suatu negara tersebut. Dari uraian tersebut dapat disimpulkan bahwa persepsi nasabah adalah proses yang berkaitan dengan masuknya pesan atau informasi yang diterima oleh nasabah, yang terdapat perbedaan sudut pandang dalam menginpretasikan informasi yag diterima dan selanjutnya akan dilakukan respon atas informasi tersebut.

Menurut kamus besar bahasa indonesia, promosi adalah perkenalan dalam rangka memajukan usaha dagang (Pusat Bahasa Departemen Pendidikan Nasional, Kamus Umum Bahasa Indonesia, Jakarta: Balai Pustaka, 2005, hlm. 898). Sebagai salah satu elemen bauran promosi, promosi penjualan merupakan unsur penting dalam kegiatan promosi produk. Promosi merupakan salah satu faktor penentu keberhasilan suatu program pemasaran. Betapapun bagusnya suatu produk, bila konsumen belum pernah mendengarnya dan tidak yakin bahwa produk itu akan berguna bagi mereka, maka mereka tidak membelinya (Subagyo, 2010).

Definisi promosi penjualan menurut American Marketing Association (AMA), yang dikutip dari bukunya Sustisna adalah: 'Sales promotion is media and non media marketing pressure applied for a predetermined, limited period of time in order to stimulate trial, increase consumer demand, or improve product quality". Definisi di atas menunjukkan bahwa promosi merupakan upaya pemasaran yang bersifat media dan non media untuk merangsang coba-coba dari konsumen, meningkatkan permintaan dari konsumen atau untuk memperbaiki kualitas produk (Sustina, 2003).

Di dalam Islam tidak ada suatu larangan, bila hamba-hambanya mempunyai rencana atau keinginan untuk berhasil dalam usahanya, hanya saja Islam melarang 
adanya manipulasi (penipuan), sebagaimana Hadits Nabi Muhammad SAW yang dikutip oleh MA. Islam menganjurkan pada Umatnya dalam memasarkan atau mempromosikan produk dan menetapkan harga tidak boleh berbohong, harus bekata jujur (benar). Oleh sebab itu salah satu karakter berdagang yang terpenting dan diridhoi oleh Allah SWT adalah kebenaran. Rasulullah SAW telah mengajarkan pada umatnya untuk berdagang dengan menjunjung tinggi etika keislaman. Dalam beraktivitas ekonomi, umat Islam dilarang melakukan tindakan bathil. Namun harus melakukan kegiatan ekonomi yang dilakukan saling ridho, sebagaimana firman Allah SWT.:

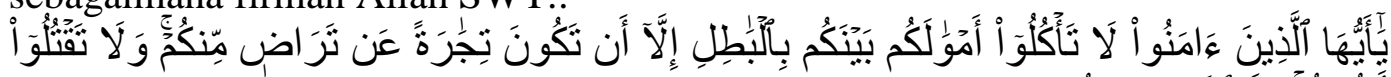

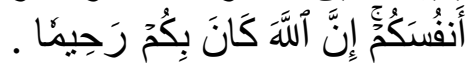

Hai orang-orang yang beriman, janganlah kamu saling memakan harta sesamamu dengan jalan yang batil, kecuali dengan jalan perniagaan yang berlaku dengan suka sama-suka di antara kamu. Dan janganlah kamu membunuh dirimu; sesungguhnya Allah adalah Maha Penyayang kepadamu. (An-Nisaa : 29) Dari uraian diatas bahwa Promosi adalah suatu bentuk komunikasi pemasaran yang berusaha menyebarkan informasi, mempengaruhi/membujuk. Sedangkan persepsi nasabah tentang Promosi adalah proses nasabah untuk memilih, mengelola dan menginterpretasikan informasi yang diperoleh atas kegiatan promosi yang dilakukan bank dan kemudian akan direspon melalui tindakan yaitu ketertarikan nasabah untuk menggunakan atau tidak produk/jasa yang ditawarkan bank.

\section{Kualitas Pelayanan}

Kualitas merupakan suatu kondisi dinamis yang berhubungan dengan produk, jasa, manusia, proses dan lingkungan yang memenuhi atau melebihi harapan (Goetsh dan Davis dalam Tjiptono dan Diana, 2015). Kualitas adalah keseluruhan ciri-ciri dan karakteristik-karakteristik dari suatu produk atau jasa dalam hal kemampuannya untuk memenuhi kebutuhan-kebutuhan yang telah ditentukan".

Pada dasarnya pelayanan adalah sesuatu yang tidak berwujud tetapi dapat memenuhi kebutuhan pelanggan atau masyarakat. Pelayanan tidak dapat mengakibatkan peralihan hak atau kepemilikan dan terdapat interaksi antara penyedia jasa dengan pengguna jasa. Kualitas pelayanan sebagai "Seberapa jauh perbedaan antara kenyataan dan harapan pelanggan atas layanan yang mereka terima/peroleh". Konsep Islam mengajarkan bahwa dalam memberikan layanan dari usaha yang dijalankan baik itu berupa barang atau jasa jangan memberikan yang buruk atau tidak berkualitas, melainkan yang berkualitas kepada orang lain (Ridwan, 2013). Hal ini sesuai firman Allah SWT.:

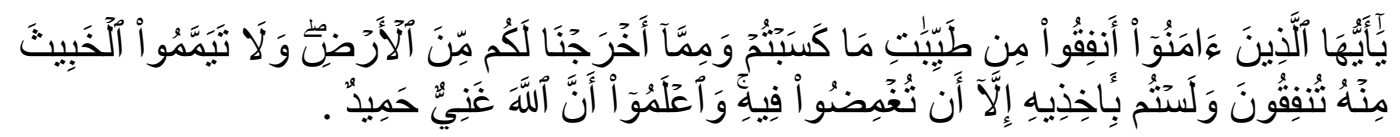

Hai orang-orang yang beriman, nafkahkanlah (di jalan allah) sebagian dari hasil usahamu yang baik-baik dan sebagian dari apa yang Kami keluarkan dari bumi untuk kamu. Dan janganlah kamu memilih yang buruk-buruk lalu kamu menafkahkan daripadanya, padahal kamu sendiri tidak mau mengambilnya 
melainkan dengan memincingkan mata terhadapnya. Dan ketahuilah, bahwa Allah Maha Kaya lagi Maha Terpuji. (Al-Baqarah : 267)

Kualitas pelayanan jasa memiliki 5 (lima) dimensi pengukuran yaitu (Sulistyorini, 2013) :

\section{1) Bukti Fisik (Tangibles)}

Yaitu kemampuan suatu perusahaan dalam menunjukkan eksistensinya kepada pihak eksternal. Penampilan, kemampuan sarana dan prasarana fisik perusahaan dan lingkungan sekitar adalah bukti fasilitas fisik atau gedung, gudang, penampilan karyawan, dan lain sebagainya. Dalam Konsep Islam pelayanan yang berkenaan dengan tampilan fisik hendaknya tidak menunjukkan kemewahan (Ridwan, 2013). Fasilitas yang membuat konsumen merasa nyaman, memang penting, namun jangan menonjolkan kemewahan Pernyataan tersebut sebagaimana yang dinyatakan dalam Al-Quran, sesuai dengan firman Allah SWT::

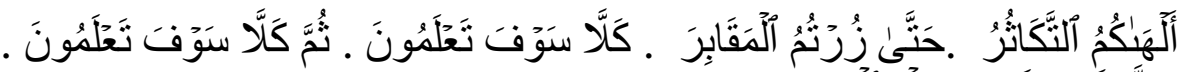

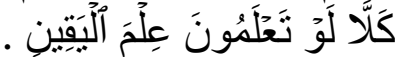

Bermegah-megahan telah melalaikan kamu. Sampai kamu masuk ke dalam kubur. Janganlah begitu, kelak kamu akan mengetahui (akibat perbuatanmu itu). Dan janganlah begitu, kelak kamu akan mengetahui. Janganlah begitu, jika kamu mengetahui dengan pengetahuan yang yakin. (At-Takaatsur : 1-5)

2) Keandalan (Reliability)

Yaitu kemampuan perusahaan untuk memberikan pelayanan sesuai yang dijanjikan dengan cepat, tepat, akurat, dan terpercaya. Kinerja harus sesuai dengan harapan pelanggan yang berarti ketepatan waktu, pelayanan yang sama untuk semua pelanggan, sikap yang simpatik, dan dengan akurasi yang tinggi. Ketepatan dan keakuratan akan menumbuhkan kepercayaan konsumen terhadap lembaga penyedia layanan jasa. Dalam konteks ini, Allah juga menghendaki setiap umatNya untuk menepati janji yang telah dibuat dan dinyatakan sebagaimana yang dinyatakan dalam Al-Quran sesui dengan firman Allah SWT.:

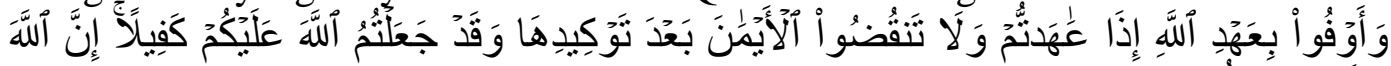

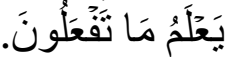

Dan tepatilah perjanjian dengan Allah apabila kamu berjanji dan janganlah kamu membatalkan sumpah-sumpah(mu) itu, sesudah meneguhkannya, sedang kamu telah menjadikan Allah sebagai saksimu (terhadap sumpah-sumpahmu itu). Sesungguhnya Allah mengetahui apa yang kamu perbuat. (An-Nahl : 91)

\section{3) Daya Tanggap (Responsiveness)}

Yaitu kemauan pegawai untuk tanggap membantu para pelanggan dan memberikan pelayanan yang cepat, tepat dengan disertai penyampaian jasa yang jelas. Dalam hal ini perusahaan tidak hanya selalu cepat tanggap pada keluhan konsumen yang timbul karena janji tidak terpenuhi, namun juga cepat tanggap menangkap perubahan yang terjadi dalam pasar, teknologi, peralatan dan perilaku konsumen. Kecepatan dan ketepatan pelayanan berkenaan dengan profesionalitas. Dalam arti seorang pegawai yang profesional dirinya akan dapat memberikan pelayanan secara tepat dan cepat. Kepercayaan yang diberikan konsumen merupakan suatu amanat. Apabila amanat tersebut disia-siakan akan berdampak pada ketidakberhasilan dan kehancuran lembaga dalam memberikan pelayanan 
kepada konsumen. Allah SWT telah mengingatkan kita tentang profesionalisme dalam menunaikan pekerjaan.Sesuai firman Allah:

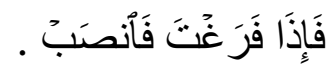

Maka apabila kamu telah selesai (dari sesuatu urusan), kerjakanlah dengan sungguh-sungguh (urusan) yang lain. (Al-Insyirah : 7)

4) Jaminan (Assurance)

Yaitu pengetahuan, kesopansantunan, dan kemampuan para pegawai perusahaan untuk menumbuhkan rasa percaya pelanggan kepada perusahaan. Variabel ini terdiri dari beberapa komponen antara lain komunikasi (communication), kredibilitas (credibility), keamanan, kompetensi (competence), dan sopan santun (cortecy). Baik buruknya layanan yang diberikan akan menentukan keberhasilan lembaga atau perusahaan pemberi jasa layanan. Dengan memberikan pelayanan yang menunjukkan kesopanan dan kelemah lembutan akan menjadi jaminan rasa aman bagi konsumen dan yang berdampak pada kesuksesan lembaga penyedia layanan jasa, Berkenaan dengan hal ini, sesuai dengan firman Allah SWT.:

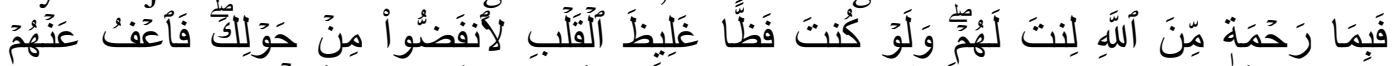

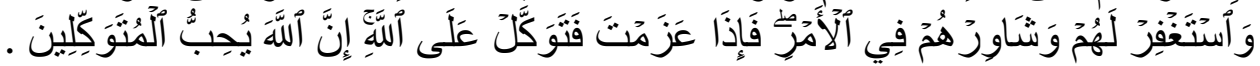

Maka disebabkan rahmat dari Allah-lah kamu berlaku lemah lembut terhadap mereka. Sekiranya kamu bersikap keras lagi berhati kasar, tentulah mereka menjauhkan diri dari sekelilingmu. Karena itu maafkanlah mereka, mohonkanlah ampun bagi mereka, dan bermusyawaratlah dengan mereka dalam urusan itu. Kemudian apabila kamu telah membulatkan tekad, maka bertawakkallah kepada Allah. Sesungguhnya Allah menyukai orang-orang yang bertawakkal kepada-Nya. (Al-Imran : 159)

5) Empati (Emphaty)

Yaitu meliputi kemudahan dalam menjalin relasi, komunikasi yang baik, perhatian pribadi dan pemahaman atas kebutuhan individu oleh para pelanggan dengan berupaya memahami keinginan konsumen. Dimana suatu perusahaan diharapkan memiliki pengertian dan pengetahuan tentang pelanggan, memenuhi kebutuhan pelanggan secara spesifik, serta memiliki waktu pengoperasian yang nyaman bagi pelanggan. Kesediaan memberikan perhatian dan membantu akan meningkatkan persepsi dan sikap positif konsumen terhadap layanan lembaga. Hal ini akan mendatangkan kesukaan, kepuasan dan meningkatkan loyalitass konsumen.

Dari uraian diatas disimpulkan bila pelayanan yang diterima atau dirasakan sesuai dengan yang diharapkan, maka kualitas dapat dipersepsikan baik dan memuaskan, akan tetapi bila kualitas pelayanan yang diterima lebih rendah daripada yang diharapkan, maka kualitas pelayanan dipersepsikan buruk. Keberhasilan bank dalam memberikan pelayanan prima kepada nasabah sangat ditentukan oleh perilaku dan karakter petugas pelayanan. Dalam perspektif Islam kualitas pelayanan haruslah sesuai dengan standarisasi syariah, agar selalu terikat dengan hukum syara. Persepsi nasabah tentang kualitas pelayanan adalah proses dimana nasabah menilai, mengelola atas kegiatan pelayanan yang dilakukan bank dan kemudian akan direspon melalui tindakan yaitu ketertarikan nasabah untuk menggunakan atau tidak produk/jasa yang ditawarkan bank. Peranan petugas pelayanan (customer service) memegang peranan penting. Untuk itu setiap perbankan harus memiliki standart pelayanan yang baik untuk menarik minat menabung nasabah. 


\section{Minat Menabung Nasabah}

Minat adalah rasa suka (senang) dan rasa tertarik pada suatu objek atau aktivitas tanpa ada yang menyuruh dan biasanya ada kecenderungan untuk mencari objek yang disenangi. Minat dalam kamus besar bahasa Indonesia diartikan sebagai sebuah kecenderungan hati yang tinggi terhadap sesuatu gairah atau keinginan. ${ }^{1}$ Pengaruh kondisi-kondisi individual dapat merubah minat seseorang. Sehingga dapat dikatakan minat sifatnya tidak stabil. ${ }^{2}$ Secara etimologi pengertian minat adalah perhatian, kesukaan (kecenderungan hati) kepada sesuatu keinginan. ${ }^{3}$ Sedangkan menurut istilah ialah sesuatu perangkat mental yang terdiri dari suatu campuran dari perasaan, harapan, pendirian, prasangka atau kecenderungan lain yang mengarahkan individu kepada suatu pilihan tertentu. ${ }^{4}$ Minat lebih dikenal sebagai keputusan pemakaian atau pembelian jasa/produk tertentu. Dalam penelitian ini untuk mengukur tingkat besarnya minat menabung nasabah maka peneliti mengambil dari teori keputusan pembelian. Minat merupakan sesuatu yang dianggap wajar bagi manusia, karena merupakan suatu keinginan yang timbul dalam diri sendiri. Seseorang yang memiliki minat lebih cenderung menilai dan melihat sisi lain dari apa yang diinginkannya.

Proses pengambilan keputusan membelian terdiri dari lima tahap yaitu ${ }^{5}$ :

1) Pengenalan Kebutuhan (need recognition) yaitu proses pengambilan keputusan konsumen membeli produk tertentu, buatan perusahaan tertentu, atau merek dagang tertentu, dimulai sejak mereka merasakan suatu kebutuhan tertentu yang belum terpenuhi. Rasa membutuhkan tersebut dapat terangsang menjadi dorongan membeli produk apabila mendapat pengaruh dari dalam maupun dari luar konsumen.

2) Pencarian alternatif informasi (alternatif search for information) yaitu intensitas upaya konsumen mencari informasi tentang produk yang mereka butuhkan ditentukan berbagai macam sebab, antara lain mendesaknya kebutuhan dan nilai produk yang dibutuhkan.

3) Penilaian berbagai macam informasi yang terkumpul (alternatif evaluation) yaitu konsumen mempergunakan informasi prooduk yang berhasil mereka kumpulkan sebagai bahan pertimbangan untuk melakukan pilihan. Keputusan membeli (purchase desicion) yaitu apabila tidak ada faktor-faktor lain yang mempengaruhinya, konsumen akan membeli produk dengan merek yang paling banyak menjanjikan atribut yang sesuai dengan kebutuhan dan keinginan mereka.

4) Evaluasi setelah pembelian (post purchase evaluation) yaitu evaluasi konsumen setelah pembelian mempunyai arti penting bagi para produsen. Pengalaman konsumen mengonsumsi produk (positif atau negatif) mempunyai

\footnotetext{
${ }^{1}$ Anton M. Moeliono, dkk, Kamus Besar Bahasa Indonesia, Jakarta: Balai Pustaka, 1999, hlm.225.

${ }^{2}$ Muhaimin, Korelasi Minat Belajar Pendidikan Jasmani terhadap hasil Belajar Pendidikan Jasmani, Semarang: IKIP, 1994,hlm.4.

${ }^{3}$ WJS.Poerwadarminta, Kamus Umum Bahasa Indonesia, Jakarta: Balai Pustaka, 1982, hlm.650.

${ }^{4}$ Andi Mappiare, Psikologi Remaja, Surabaya: Usaha Nasional, 1997, hlm.62.

${ }^{5}$ Rangkuti, Freddy, Customer Service Satisfaction \& Call Center, Jakarta: PT. Gramedia Pustaka Utama, 2013
} 
pengaruh dalam pengambilan keputusan membeli lagi produk yang sama pada saat mereka membutuhkan lagi.

Menabung adalah menyimpan uang (dicelengan, pos, bank, dsb). Seacara luas menabung dapat diartikan sebagai suatu kegiatan menyisihkan sebagian dari pendapatannya untuk dikumpulkan sebagai cadangan di hari depan. Menabung adalah tindakan yang dianjurkan oleh umat Islam, karena dengan menabung berarti seorang muslim mempersiapkan diri untuk pelaksanaan perencanaan masa yang akan datang sekaligus untuk menghadapi hal-hal yang tak diinginkan. Dalam ayat Al-Quran terdapat ayat-ayat yang secara tidak langsung telah memerintahkan kaum muslimin untuk mempersiapkan hari esok secara lebih baik. Dari uraian di atas dapat disimpulkan bahwa minat menabung adalah perhatian, keputusan, kesukaan (kecenderungan hati) kepada sesuatu keinginan yang datang dari diri sendiri untuk menyimpan sebagian pendapatan dalam mempersiapkan diri untuk pelaksanaan perencanaan masa yang akan datang.

\section{Penelitian Terdahulu yang Relevan}

1. Tesis

Penelitian dilakukan oleh Dian Ariani (Medan, 2007) dengan judul 'Persepsi Masyarakat Umum Tehadap Bank Syariah di Medan' dengan hasil sebagai berikut Penelitian terdahulu untuk mengetahui apakah tingkat, pendidikan, usia dan pelayanan mempengaruhi persepsi masyarakat terhadap bank syariah di Medan. Menggunakan data primer, yaitu dengan menyebar kuesioner yang berisi daftar pertanyaan yang berhubungan dengan penelitian kepada responden. Hasil penelitian ini adalah adanya hubungan yang signifikan dan positif antara variabel pendidikan, usia, dan pelayanan dengan persepsi masyarakat umum terhadap Bank Syariah di Medan.

2. Jurnal Penelitian

Penelitian dilakukan oleh Itarahmat (Kudus, 2014) dengan judul 'Pengaruh Persepsi Tentang Bank Syariah Terhadap Minat Menggunakan Produk Di BNI Syariah Semarang', Tujuan penelitian adalah menguji secara empiris pengaruh persepsi tentang bank syariah terhadap minat menggunakan produk di BNI Syariah Semarang. Jenis penelitian yang dilakukan adalah kuantitatif. Variabel bebas yang digunakan adalah (Persepsi tentang bunga bank, Persepsi tentang sistem bagi hasil dan Persepsi tentang produk). Pengumpulan data dilakukan dengan survey mengambil sampel secara langsung dari populasi, sehingga ditemukan hubungan-hubungan antarvariabel. Hasil penelitian ini adalah :

Persepsi tentang bunga, sistem bagi hasil dan produk bank berpengaruh secara positif dan signifikan terhadap minat menggunakan produk bank syariah.

Penelitian dilakukan oleh Dian Sulistyorini (Kendal, 2013) dengan judul: 'Pengaruh Kinerja Pelayanan Terhadap Kepuasan Nasabah (Studi Kasus pada PT.Bank (Persero) Tbk Kantor Cabang Kendal'. Tujuan penelitian adalah untuk mengetahui pengaruh kinerja pelayanan terhadap kepuasan nasabah pada PT.Bank (Persero) BRI kantor cabang Kendal. Jenis penelitian yang digunakan adalah kuantitatif. Variabel yang digunakan adalah keadaan fisik (Tangibles), keandalan 
(Reliability), data tanggap (Responsiveness), Jaminan (Assurance), dan perhatian (Empathy) serta satu variabel terikat yaitu Kepuasan Nasabah. Hasil penelitian ini adalah variable kinerja pelayanan jasa yang meliputi Tangibles, Reliability, Responsivenes, Assurance dan Empathy berpengaruh secara simultan atau bersama-sama terhadap kepuasan nasabah PT. Bank BRI Cabang Kendal.

Gambar Kerangka Fikir Penelitian

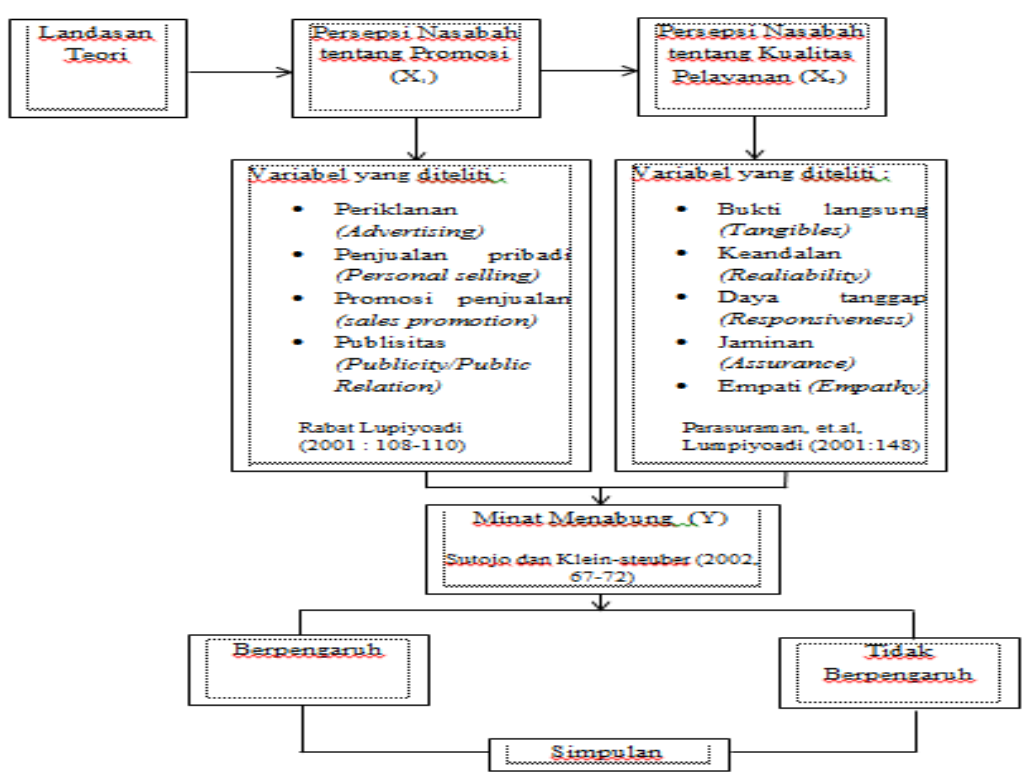

Tabel 2.1

Hipotesis

Hipotesis Persepsi Nasabah tentang Promosi :

$\mathrm{H}_{0}$ : Tidak Ada Pengaruh Persepsi Nasabah tentang Promosi Terhadap Minat Menabung.

$\mathrm{H}_{\mathrm{a}}$ : Adanya Pengaruh Persepsi Nasabah tentang Promosi Terhadap Minat Menabung.

Hipotesis Persepsi Nasabah tentang Kualitas Pelayanan :

$\mathrm{H}_{0}$ : Tidak Ada Pengaruh Persepsi Nasabah tentang Kualitas Pelayanan Terhadap Minat Menabung.

$\mathrm{H}_{\mathrm{a}}$ : Adanya Pengaruh Persepsi Nasabah tentang Kualitas Pelayanan Terhadap Minat Menabung.

Hipotesis Persepsi Nasabah tentang Promosi dan Kualitas Pelayanan : $\mathrm{H}_{0}$ : Tidak Ada Pengaruh Persepsi Nasabah tentang Promosi dan Kualitas Pelayanan Terhadap Minat Menabung.

$\mathrm{H}_{\mathrm{a}}$ : Adanya Pengaruh Persepsi Nasabah tentang Promosi dan Kualitas Pelayanan Terhadap Minat Menabung. 


\section{METODE PENELITIAN}

Penelitian ini menggunakan jenis penelitian kuantitatif. Penelitian kuantitatif merupakan suatu pendekatan penelitian yang bersifat obyektif, menekankan pada pengujian teori-teori melalui pengukuran variabel-variabel penelitian dengan angka dan melakukan analisis data dengan metode pengujian statistik. Penelitian ini dilakukan pada bank bjb syariah Kantor Cabang Pembantu Cikarang yang beralamat di Jl. RE Martadinata No. 04 Cikarang Utara, No Tlp (021)-89106642, 89106563. Alasan dipilihnya tempat penelitian ini adalah lokasi yang strategis dan bank bjb syariah salah satu bank yang memberikan kesempatan buat peneliti untuk melakukan penelitian.

\section{Definisi Operasional Variabel dan Pengukuran Variabel Penelitian}

\section{Variabel Independen/variabel bebas $(X)$}

\section{a. Persepsi Nasabah tentang Promosi $\left(\mathbf{X}_{1}\right)$}

Promosi yang dilakukan bank melalui media periklanan (advertising), promosi penjualan (sales promotion), publisitas (publicity/public rellation), dan melalui penjualan pribadi (personal selling).

Indikator-indikator yang terkait dengan promosi adalah :

1) Variabel Periklanan (Advertising)

Merupakan sarana promosi yang digunakan oleh bank dengan tujuan untuk membangun kesadaran (awareness) terhadap keberadaan produk/jasa yang ditawarkan. Media yang dapat digunakan seperti pemasangan billboard di jalanjalan strategis, percetakan brosur baik disebarkan di setiap cabang atau pasar pembelanjaan, pemasangan spanduk, melalui koran, majalah, radio, televisi, dan media lainnya. Indikator-indikator yang terkait dengan (advertising) adalah:

- Saya tertarik menabung di bank karena media iklan lewat internet, televisi dan radio.

- Saya tertarik menabung di bank karena media iklan lewat majalah, koran dan brosur.

2) Variabel Promosi Penjualan (Sales Promotion)

Promosi penjualan adalah semua kegiatan yang dimaksudkan untuk meningkatkan arus produk dan jasa dari produsen (bank) sampai pada penjualan akhirnya (nasabah). Misal pemberian Pemberian bunga khusus (special rate), Pemberian intensif, Pemberian cenderamata. Indikator-indikator yang terkait dengan (Sales Promotion) adalah:

- Saya tertarik menabung di bank karena pemberian cenderamata atau kenang-kenangan yang diberikan bank kepada nasabah.

- Saya tertarik menabung di bank karena pemberian hadiah yang bermanfaat untuk nasabah.

\section{3) Variabel Publisitas (Publicity/Public Rellation)}

Publisitas merupakan kiat pemasaran produk/jasa bank yang tidak berhubungan dengan nasabah saja tetapi juga berhubungan dengan kumpulan kepentingan publik yang lebih besar yaitu masyarakat umum. Publisitas ini menjadi kegiatan 
promosi untuk memancing nasabah melalui kegiatan seperti pameran, bakti sosial, events serta mensponsori beberapa acara. Indikator-indikator yang terkait dengan (Publicity/Public Rellation) adalah:

- Saya tertarik menabung di bank karena publisitas yang dilakukan bank melalui kegiatan pameran dan bakti sosial.

- Saya tertarik menabung di bank karena bank mensponsori beberapa acara atau events tertentu.

4) Variabel Penjualan Pribadi (Personal Selling)

Penjualan Pribadi lebih banyak dilakukan oleh petugas customer service pada dunia perbankan. Dalam hal ini customer service memegang peranan sebagai pembinaan hubungan dengan masyarakat atau public relation. Sifat personal selling dapat dikatakan luwes karena tenaga penjual dapat secara langsung menyesuaikan penawaran penjualan dengan kebutuhan dan perilaku masingmasing calon nasabah. Indikator-indikator yang terkait dengan (Personal Selling) adalah:

- Saya tertarik menabung di bank karena promosi yang dilakukan bank kepada nasabahnya secara langsung.

- Saya tertarik menabung di bank karena pelayanan customer service sangat ramah dan menarik.

\section{b. Persepsi Nasabah tentang Kualitas Pelayanan $\left(\mathbf{X}_{2}\right)$}

Dimensi pengukuran untuk kualitas pelayanan adalah bukti fisik (tangibles), keandalan (reliability), daya tanggap (responsiveness), jaminan (assurance) dan empati (empathy). Indikator-indikator yang terkait dengan kualitas pelayanan adalah :

1) Variabel Bukti Fisik (Tangibles)

Bukti Fisik (Tangibles) yaitu kemampuan suatu perusahaan dalam menunjukkan eksistensinya kepada pihak eksternal. Penampilan, kemampuan sarana dan prasarana fisik perusahaan dan lingkungan sekitar adalah bukti fasilitas fisik atau gedung, gudang, penampilan karyawan, dan lain sebagainya. Indikator-indikator yang terkait dengan Tangibles ::

- $\quad$ Kerapian penampilan karyawan bank.

- Kenyamanan fasilitas ruangan banking hall (tempat duduk, AC).

2) Variabel Keandalan (Reliability)

Keandalan (Reliability) yaitu kemampuan perusahaan untuk memberikan pelayanan sesuai yang dijanjikan dengan cepat, tepat, akurat, dan terpercaya. Kinerja harus sesuai dengan harapan pelanggan yang berarti ketepatan waktu, pelayanan yang sama untuk semua pelanggan, sikap yang simpatik, dan dengan akurasi yang tinggi. Indikator-indikator yang terkait dengan Reliability:

- Kecepatan dan ketepatan karyawan dalam melakukan transaksi.

- Keakuratan dalam memberikan informasi kepada nasabah.

3) Variabel Daya Tanggap (Responsiveness)

Daya Tanggap (Responsiveness) yaitu kemampuan pegawai untuk tanggap membantu para pelanggan dan memberikan pelayanan yang cepat, tepat dengan disertai penyampaian jasa yang jelas. Dalam hal ini perusahaan tidak hanya selalu cepat tanggap pada keluhan konsumen yang timbul karena janji tidak terpenuhi, 
namun juga cepat tanggap menangkap perubahan yang terjadi dalam pasar, teknologi, peralatan dan perilaku konsumen.

Indikator-indikator yang terkait dengan Responsiveness :

- Kecepatan karyawan dalam merespon keluhan nasabah.

- Kesediaan dan ketanggapan karyawan dalam melayani nasabah.

4) Variabel Jaminan (Assurance)

Assurance yaitu pengetahuan, kesopansantunan, dan kemampuan para pegawai perusahaan untuk menumbuhkan rasa percaya pelanggan kepada perusahaan. Variabel ini terdiri dari beberapa komponen antara lain komunikasi, kredibilitas, keamanan, kompetensi, dan sopan santun. Indikator-indikator yang terkait dengan Assurance :

- Karyawan bank bersikap ramah dan sopan kepada nasabah.

- Karyawan memiliki pengetahuan yang baik mengenai produk bank dan mampu mengenali calon nasabah dengan baik.

\section{5) Variabel Empati (Emphaty)}

Emphaty yaitu meliputi kemudahan dalam menjalin relasi, komunikasi yang baik, perhatian pribadi dan pemahaman atas kebutuhan individu para pelanggan dengan berupaya memahami keinginan konsumen. Dimana suatu perusahaan diharapkan memiliki pengertian dan pengetahuan tentang pelanggan, memenuhi kebutuhan pelanggan secara spesifik, serta memiliki waktu pengoperasian yang nyaman bagi pelanggan. Kesediaan memberikan perhatian dan membantu akan meningkatkan persepsi dan sikap positif konsumen terhadap layanan lembaga. Hal ini akan mendatangkan kesukaan, kepuasan dan meningkatkan loyalitass konsumen. Indikator-indikator yang terkait dengan Emphaty :

- Karyawan mampu berkomunikasi dengan baik sehingga menciptakan ketertarikan terhadap loyalitas nasabah.

- Karyawan mampu memahami dan memberikan solusi setiap kebutuhan nasabah.

\section{Variabel Dependen/variabel terikat (Y)}

Variabel dependen merupakan variabel yang dipenggaruhi atau yang menjadi akibat, karena adanya variabel bebas. Dalam penelitian ini yang menjadi variabel dependen yaitu Minat Menabung Nasabah yang merupakan tingkat ketertarikan, rasa suka/senang terhadap kualitas pelayanan dan promosi yang diberikan bank kepada nasabah. Minat dalam kamus besar bahasa Indonesia diartikan sebagai sebuah kecenderungan hati yang tinggi terhadap sesuatu gairah atau keinginan. Minat merupakan kecenderungan seseorang untuk menentukan pilihan aktivitas.

Indikator-indikator yang terkait dengan Minat Menabung Nasabah adalah :

- Saya tertarik untuk menabung di bank karena saya percaya pada kinerja bank.

- Saya tertarik menabung di bank karena bank mempu memenuhi kebutuhan nasabah.

- Saya tertarik menabung di bank karena berbagai informasi menarik yang saya dapatkan tentang bank.

- Saya tertarik menabung di bank karena saya merasa puas atas pelayanan dan promosi yang diberikan bank.

- Saya mempunyai keinginan untuk berpindah ke bank lain 


\section{Populasi dan Sampel}

Populasi yang diambil adalah nasabah bank bjb syariah Kantor Cabang Pembantu Cikarang, dengan jumlah populasi 3000 nasabah, informasi didapat dari pimpinan bank bjb Syariah Cikarang (Ibu Fierliya). Nasabah yang aktif di bank bjb syariah Kantor Cabang Pembantu Cikarang tidak keseluruhan berjumlah 3000 nasabah. Sesuai informasi Customer Service (Bapak Fajar), nasabah yang aktif bertransaksi hanya berjumlah 2500 nasabah. Sehingga untuk pengambilan sampel peneliti mengambil jumlah nasabah yang aktif saja. Jika diketahui jumlah nasabah aktif sekitar 2500, dan yang diinginkan sampling error 5\% maka perhitungan sebagai berikut :

$n=\frac{N}{1+N e^{2}}$

$n=\frac{2500}{1+\left(2500 \times 0,05^{2}\right)}$

$n=344,8$

Untuk pengambilan sampel dalam penelitian ini satu hal yang perlu dipahami, bahwa ukuran atau besarnya sampel hanyalah merupakan salah satu aspek yang digunakan untuk menilai keabsahan suatu sampel. Oleh karena itu tidaklah benar apabila suatu penelitian yang menetapkan besarnya sampel sebesar 10 - 25 persen atau lebih dari populasi yang ada. Seberapa besar jumlah sampel yang seharusnya diambil adalah fungsi dari variasi pada parameter populasi yang tercakup dalam penelitian ${ }^{6}$. Dengan demikian jumlah sampel yang dipilih sebanyak 100 responden.

\section{Teknik Pengambilan Data}

Pengumpulan data berdasarkan sumber datanya dibedakan menjadi pengumpulan data primer dan pengumpulan data sekunder. Dalam penelitian ini menggunakan dua teknik pengumpulan data sekaligus yaitu data primer dan data sekunder, keterangan sebagai berikut :

Data primer yang digunakan adalah :

a. Kuesioner, yaitu membagikan daftar pertanyaan kepada nasabah bank bjb syariah Kantor Cabang Pembantu Cikarang, yang diajukan dan disusun berdasarkan variabel yang telah ditentukan dengan menyediakan jawaban alternatif.

b. Observasi atau pengamatan, yaitu metode pengumpulan data mengenai perilaku atau fenomena tertentu tanpa mengajukan pertanyaan (melalui interaksi dengan individu yang diteliti). Observasi yang dilakukan dalam penelitian ini yaitu Observasi secara langsung.

Data sekunder yang digunakan adalah salah satunya:

a. Internet

\footnotetext{
${ }^{6}$ Sanusi, A, Metodologi Penelitian Bisnis, Jakarta : Penerbit Salemba Empat, 2011
} 
- Ridwan, Kualitas Pelayanan Dalam Islam, [Online], http://ridwan202.wordpress.com/2013/02/11/kualitaspelayanan-dalam-islam, Februari 2013.

- http://www.konsistensi.com/2014/08/uji-normalitas-grafikhistogram-plot.html. Diakses tanggal 7 Agustus 2017.

- $\quad$ www.junaidichaniago.wordpress.com

b. Buku - Buku

- Penelitian Metode dan Analisis (Penerbit Cv Agung, 2010)

- Marketing in Business (Penerbit Mitra Wacana Media, 2010)

- Customer Service Satisfaction \& Call Center (Penerbit Gramedia Pustaka Utama, 2013)

c. Jurnal - Jurnal

- Analisis Marketing Mix Terhadap Kepuasan Konsumen dengan Keputusan Pembelian Sebagai Variabel Intervening dalam Membeli Notebook pada PT Surya Wincom. Jurnal Skripsi Universitas Darma Cendika, Surabaya, 2015.

- Pengaruh Kinerja Pelayanan Terhadap Kepuasan Nasabah (Studi Kasus pada PT. Bank BRI (Persero) Tbk Kantor Cabang Kendal). Jurnal Universitas Diponegoro, Semarang, 2013.

- Pengaruh Persepsi tentang Bank Syariah terhadap Minat Menggunakan Produk di BNI Syariah Semarang, Jurnal pada STAIN kudus, Jawa, 2014.

d. Dokumen - Dokumen

- Dokumen dari bank bjb syariah Kantor Cabang Pembantu Cikarang yaitu Pedoman Penghimpunan Dana.

- Dokumen dari bank bjb syariah Kantor Cabang Pembantu Cikarang yaitu Pedoman dan Juklak Produk Tabungan Anak..

- Dokumen dari bank bjb syariah Kantor Cabang Pembantu Cikarang yaitu Pedoman Produk Simpanan Pelajar (SimPel iB).

- Dokumen dari bank bjb syariah Kantor Cabang Pembantu Cikarang yaitu Arsitektur Standar Layanan bagi Frontliners.

\section{METODE PENELITIAN}

Penelitian ini merupakan penelitian yang menggunakan metode deskriptifkorelasional dengan menggunakan pendekatan kuantitatif.

Teknik Analisis Data

a. Pengujian Instrumen

b. Uji Validitas

c. Uji Reliabilitas

d. Uji Asumsi Klasik

1) Uji Normalitas

2) Uji Asumsi Multikolinearitas

3) Uji Asumsi Autokorelasi

4) Uji Asumsi Heteroskedastisitas 
e. Uji Analisis Regresi Berganda

Analisis Regresi Linier Ganda

1. Uji - $\mathrm{t}$

2. Uji-F

f. Analisis Korelasi

Uji Koefisien Determinasi $\left(\mathrm{R}^{2}\right)$

\section{HASIL PENELITIAN DAN PEMBAHASAN}

\section{Hasil Penelitian}

Pendirian bank bjb syariah diawali dengan pembentukan Devisi/Unit Usaha Syariah oleh PT Bank Pembangunan Daerah Jawa Barat dan Banten Tbk. Pada tanggal 20 Mei 2000, dengan tujuan untuk memenuhi kebutuhan masyarakat Jawa Barat yang dimulai tumbuh keinginannya untuk menggunakan jasa perbankan syariah pada saat itu.

Setelah 10 (sepuluh) tahun operasional Divisi/Unit Usaha Syariah, manajemen PT Bank Pembangunan Daerah Jawa Barat dan Banten Tbk, berpandangan bahwa untuk untuk mempercepat pertumbuhan usaha syariah serta mendukung program Bank Indonesia yang menghendaki peningkatan share perbankan syariah, maka dengan persetujuan Rapat Umum Pemegang Saham PT Bank Pembangunan Daerah Jawa Barat dan Banten Tbk, diputuskan untuk menjadikan Devisi/Unit Usaha Syariah menjadi Bank Umum Syariah.

Analisis regresi linier ganda (dikenal uji asumsi klasik) dilakukan untuk membuktikan bahwa model persamaan regresi linier ganda dapat diterima secara ekonometrika karena mempengaruhi penaksiran BLUE (Best Liner Unbiased Estimator) artinya penaksiran tidak bias, linier dan konstanta. Uji asumsi terdiri dari uji normalitas, multikolinieritas, autokorelasi, dan heteroskedastisitas. Hasil uji asumsi klasik sebagai berikut :

\section{1) Uji Normalitas}

Gambar 4.7

Uji Normalitas

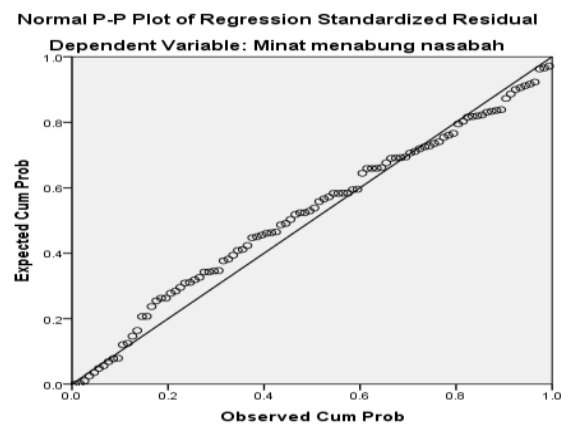

Sumber : Hasil Output olahan SPSS 21 
Berdasarkan grafik diatas tampak bahwa titik-titik menyebar disekitar garis diagonal, serta penyebarannya mengikuti arah garis diagonal, maka dapat disimpulkan bahwa model regresi memenuhi asumsi normalitas.

\section{2) Uji Multikolinieritas}

Tabel 4.8

Uji Multikolinieritas

Coefficients $^{\mathrm{a}}$

\begin{tabular}{|rl|r|c|}
\hline Model & \multicolumn{2}{|c|}{ Collinearity Statistics } \\
\cline { 3 - 4 } 1 & \multicolumn{1}{|c|}{ Tolerance } & \multicolumn{1}{c|}{ VIF } \\
\hline & $\begin{array}{l}\text { Persepsi nasabah tentang } \\
\text { promosi }\end{array}$ & .996 & 1.005 \\
$\begin{array}{l}\text { Persepsi nasabah tentang } \\
\text { kualitas pelayanan }\end{array}$ & .996 & 1.005 \\
\hline
\end{tabular}

a. Dependent Variable: Minat menabung nasabah

Sumber : Hasil Output olahan SPSS 21

Dari tabel 4.8 tersebut diperoleh masing-masing variabel independen memiliki nilai Tolerance $=0.996$ dan VIF 1.005 . Karena nilai Tolerance lebih besar dari pada persyaratan minimal $(0.996>0.2)$ dan nilai VIF lebih rendah dari persyaratan maksimal $(1.005<10)$ maka dapat disimpulkan bahwa analisis regresi linier ganda tidak memiliki masalah multikolinieritas (model yang dikembangkan sudah tepat).

\section{3) Uji Autokorelasi}

Tabel 4.9

Uji Autokorelasi

Model Summary

\begin{tabular}{|l|r|r|r|r|r|}
\hline Model & \multicolumn{1}{|c|}{$\mathrm{R}$} & R Square & \multicolumn{1}{c|}{$\begin{array}{c}\text { Adjusted R } \\
\text { Square }\end{array}$} & $\begin{array}{c}\text { Std. Error of the } \\
\text { Estimate }\end{array}$ & Durbin-Watson \\
\hline 1 & $.468^{\mathrm{a}}$ & .219 & .203 & .58943 & 1.730 \\
\hline
\end{tabular}

a. Predictors: (Constant), Persepsi nasabah tentang kualitas pelayanan, Persepsi nasabah tentang promosi

b. Dependent Variable: Minat menabung nasabah

\section{Sumber : Hasil Output olahan SPSS 21}

Berdasarkan tabel 4.9 di atas, diketahui nilai DW 1.730, selanjutnya nilai tersebut bandingkan dengan nilai tabel signifikan 5\%, jumlah sampel $\mathrm{n}=100$ dan $(\mathrm{k}=2)$. Maka dapat dilihat hasil dari Tabel Durbin Watson (DW), $\alpha=5 \%$ hasil nya adalah : nilai $\mathrm{dl}=1.633(4-\mathrm{dl}=2.367)$ dan $\mathrm{du}=1.715(4-\mathrm{du}=2.285)$. Sehingga jika d terletak antara du dan (4-dL), maka hipotesis nol diterima. Hasilnya sebagai berikut:

$\mathrm{du}<\mathrm{dw}<(4-\mathrm{dL})=1.715<1.730<2.367$

Dari hasil diatas maka $\mathrm{H}_{0}$ diterima yang berarti tidak ada autokorelasi.

\section{4) Uji Heteroskedastisitas}

Gambar 4.8

Uji Heteroskedastisitas

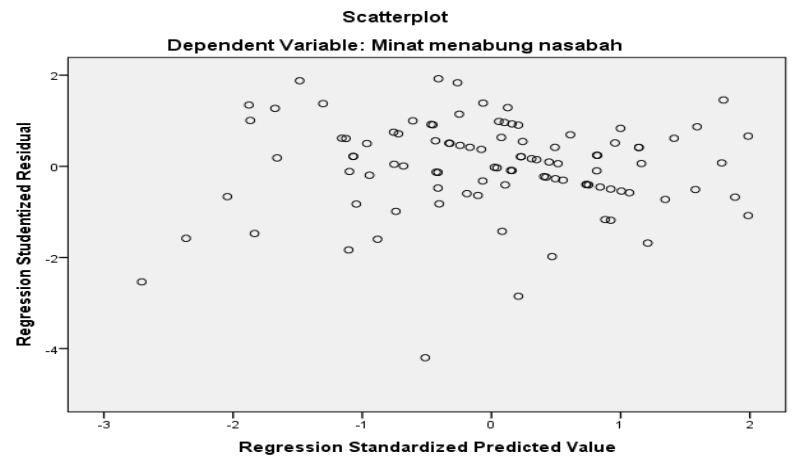


Sumber : Hasil Output olahan SPSS 21

Dari grafik scatterplots diatas, terlihat bahwa titik-titik hasil perhitungan (perpotongan antara nilai residual dan prediksi) relatif menyebar secara acak di atas dan dibawah titik origin serta tidak membentuk pola tertentu. $\mathrm{Hal}$ ini dapat dikatakan bahwa analisis regresi ganda $\mathrm{X}_{1}$ dan $\mathrm{X}_{2}$ terhadap $\mathrm{Y}$ benarbenar linier karena tidak memiliki masalah heteroskedastisitas sehingga analisis regresi linier ganda dapat dilanjutkan.

\section{Pengujian Hipotesis Penelitian}

\section{Analisis Regresi Linier Ganda}

Analisis regresi linier ganda digunakan untuk menguji pengaruh beberapa variabel dependen terhadap satu variabel dependen dengan tipe data metrik (interval dan rasio). Model persamaan regresi linier ganda dalam penelitian ini adalah sebagai berikut :

$\hat{\mathrm{Y}}=a+b_{1} x_{1}+b_{2} x_{2}+e$

Dalam analisis data, penelitian ini menggunakan program SPSS 21. Adapun hasil analisis tersebut sebagai berikut :

Penafsiran hasil pada analisis regresi linier ganda ini dibagi menjadi dua, pertama melihat pengaruh secara parsial persepsi nasabah tentang promosi dan kualitas pelayanan terhadap minat menabung nasabah, dan kedua melihat pengaruh secara simultan/gabungan persepsi nasabah tentang promosi dan kualitas pelayanan terhadap minat menabung nasabah.

a. Melihat pengaruh persepsi nasabah tentang promosi dan kualitas pelayanan secara parsial terhadap minat menabung nasabah.

Untuk melihat besarnya pengaruh persepsi nasabah tentang promosi dan kualitas pelayanan secara parsial terhadap minat menabung nasabah secara sendiri-sendiri/ parsial, digunakan Uji-t.

1) Pengaruh persepsi nasabah tentang promosi terhadap minat menabung nasabah. ( $X_{1}$ terhadap $\left.Y\right)$

Tabel 4.10

Uji R \& $\mathrm{R}^{2},\left(\mathrm{X}_{1}\right.$ terhadap $\left.\mathrm{Y}\right)$

Model Summaryb

\begin{tabular}{|l|r|r|r|c|}
\hline Model & \multicolumn{1}{|c|}{$\mathrm{R}$} & $\mathrm{R}$ Square & \multicolumn{1}{c|}{$\begin{array}{c}\text { Adjusted } \mathrm{R} \\
\text { Square }\end{array}$} & $\begin{array}{c}\text { Std. Error of the } \\
\text { Estimate }\end{array}$ \\
\hline 1 & $.231^{\mathrm{a}}$ & .053 & .043 & .64573 \\
\hline
\end{tabular}

a. Predictors: (Constant), Persepsi nasabah tentang promosi

b. Dependent Variable: Minat menabung nasabah

Sumber : Hasil Output olahan SPSS 21

Hasil uji R, uji $\mathrm{R}^{2}$ dan Uji-t adalah :

Pertama : Hasil Uji R ( $\mathrm{X}_{1}$ terhadap Y), berdasarkan tabel 4.10 besarnya nilai $\mathrm{R}$ adalah 0.231 , nilai tersebut untuk melihat hubungan satu variabel dengan variabel lainnya tetapi tidak menjelaskan hubungan sebab akibat. Hubungan antar variabel 
ditunjukkan oleh nilai koefisien korelasi sebesar 0.231 artinya hubungan antara "persepsi nasabah tentang promosi terhadap minat menabung' adalah rendah tapi positif . interval koefisien korelasi $0.200-0.399=$ Kategori Hubungan Rendah (Lihat pada nilai korelasi dan kategori hubungan).

Kedua : Hasil Uji R Square ( $\mathrm{X}_{1}$ terhadap $\left.\mathrm{Y}\right)$, berdasarkan tabel 4.10 diatas besarnya $\mathrm{R}$ square $\left(\mathrm{r}^{2}\right)$ adalah 0.053 Angka tersebut digunakan untuk melihat besarnya pengaruh persepsi nasabah tentang promosi terhadap minat menabung nasabah, dengan cara menghitung koefisien determinasi (KD) dengan menggunakan rumus sebagai berikut :

$$
\begin{aligned}
& \mathrm{KD}=\mathrm{r}^{2} \times 100 \% \\
& \mathrm{KD}=0.053 \times 100 \% \\
& \mathrm{KD}=5.3 \%
\end{aligned}
$$

Angka tersebut mempunyai maksud bahwa pengaruh persepsi nasabah tentang promosi terhadap minat menabung nasabah secara parsial adalah $5.3 \%$, sedangkan sisanya sebesar $94.7 \%(100 \%-5.3 \%)$ dipengaruhi oleh faktor lain.

Ketiga : Hasil Uji-t penelitian ( $\mathrm{X}_{1}$ terhadap $\mathrm{Y}$ )

Tabel 4.11

\begin{tabular}{|c|c|c|c|c|c|c|}
\hline \multirow[t]{2}{*}{ Model } & & \multicolumn{2}{|c|}{$\begin{array}{l}\text { Unstandardized } \\
\text { Coefficients }\end{array}$} & \multirow{2}{*}{$\begin{array}{c}\text { Standardized } \\
\text { Coefficients } \\
\text { Beta }\end{array}$} & \multirow[t]{2}{*}{$\mathrm{t}$} & \multirow[t]{2}{*}{ Sig. } \\
\hline & & $\mathrm{B}$ & Std. Error & & & \\
\hline & (Constant) & 2.808 & .346 & & 8.108 & .000 \\
\hline 1 & $\begin{array}{l}\text { Persepsi nasabah } \\
\text { tentang promosi }\end{array}$ & .204 & .087 & .231 & 2.345 & .021 \\
\hline
\end{tabular}

Uji-t SPSS ( $\mathrm{X}_{1}$ terhadap Y)

Coefficients $^{\mathrm{a}}$

Hasil Uji-t penelitian ( $\mathrm{X}_{1}$ terhadap $\mathrm{Y}$ ), berdasarkan tabel 4.11 diatas besarnya $\mathrm{t}$ adalah 2.345. Untuk menentukan besarnya $t$ tabel adalah sebagai berikut :

1. Menghitung besarnya $t$ tabel yaitu dengan Derajat kebebasan (DK) dengan ketentuan : $\mathrm{DK}=\mathrm{n}-\mathrm{k}$, atau (jumlah sampel - variabel yang diteliti) yaitu $100-2$ $=98$. Dari ketentuan tersebut diperoleh t tabel sebesar 1.984 (table critical value for the t distribution).

2. Melihat penentuan Hipotesis awal yang peneliti tulis pada BAB 2 .

$\mathrm{H}_{0}$ : tidak ada pengaruh antara persepsi nasabah tentang promosi dengan terhadap menabung nasabah.

$\mathrm{H}_{\mathrm{a}}$ : ada pengaruh antara persepsi nasabah tentang kualita pelayanan terhadap minat menabung nasabah.

3. Menentukan kriteria uji hipotesis sebagai berikut :

Jika $\mathrm{t}_{\text {penelitian }}>\mathrm{t}$ tabel maka $\mathrm{H}_{0}$ ditolak dan $\mathrm{H}_{\mathrm{a}}$ diterima

Jika $\mathrm{t}_{\text {penelitian }}<\mathrm{t}$ tabel maha $\mathrm{H}_{0}$ diterima dan $\mathrm{H}_{\mathrm{a}}$ ditolak

Ketentuan taraf signifikansi 0.05 dengan ketentuan jika probabilitas $t$ hitung lebih kecil dari pada taraf uji penelitian $\left(\mathrm{Sig} \mathrm{t}<\alpha\right.$ ) maka $\mathrm{H}_{0}$ ditolak dan $\mathrm{H}_{\mathrm{a}}$ diterima yang memiliki arti bahwa variabel independen secara parsial memiliki pengaruh signifikan terhadap variabel dependen begitu sebaliknya jika probabilitas hitung 
lebih besar dari pada taraf uji penelitian (Sig $\mathrm{t}>\alpha$ ) maka $\mathrm{H}_{\mathrm{a}}$ ditolak dan $\mathrm{H}_{0}$ diterima yang memiliki arti bahwa variabel independen secara parsial tidak signifikan terhadap variabel dependen.

\section{Membuat keputusan :}

Berdasarkan pada hasil perhitungan, diperoleh angka $\mathrm{t}$ penelitian sebesar $2.345>\mathrm{t}$ tabel sebesar 1.984. Sehingga $\mathrm{H}_{0}$ ditolak dan $\mathrm{H}_{\mathrm{a}}$ diterima. Artinya ada pengaruh antara pesepsi nasabah tentang promosi dengan minat menabung nasabah. Taraf signifikansi sebesar $0.021<0.05$ maka $\mathrm{H}_{0}$ ditolak dan $\mathrm{H}_{\mathrm{a}}$ diterima, arinya bahwa variabel persepsi nasabah tentang promosi secara parsial memiliki pengaruh signifikan terhadap variabel minat menabung nasabah.

Keempat : Hasil Analisis Regresi Ganda $\mathrm{X}_{1}$ terhadap Y

Tabel 4.12

Analisis Regresi Linier Ganda ( $\mathrm{X}_{1}$ terhadap Y) Coefficients ${ }^{a}$

\begin{tabular}{|c|c|c|c|c|c|}
\hline \multirow{2}{*}{ Model } & \multicolumn{2}{|l|}{ Unstandardized Coefficients } & $\begin{array}{c}\text { Standardized } \\
\text { Coefficients }\end{array}$ & & \multirow{2}{*}{ Sig. } \\
\cline { 2 - 5 } & $\mathrm{B}$ & Std. Error & Beta & & \\
\hline \multirow{2}{*}{$\begin{array}{c}\text { (Constant) } \\
\text { Persepsi nasabah tentang } \\
\text { promosi }\end{array}$} & 2.808 & .346 & & 8.108 & .000 \\
& .204 & .087 & .231 & 2.345 & .021 \\
\hline
\end{tabular}

a. Dependent Variable: Minat menabung nasabah Sumber : Hasil Output olahan SPSS 21

Berdasarkan analisis tabel 4.12 maka diperoleh persamaan regresi dengan nilai point sebagai berikut : $\hat{Y}=2.808+0.204 X_{1}+$ e.

Artinya bahwa : Nilai minat menabung nasabah sebesar 2.808 jika tidak ada $\mathrm{X}_{1}$. Sehingga untuk meningkatkan minat menabung tersebut perlu adanya persepsi nasabah tentang promosi yang baik yang diberi nilai 0.204 . Intinya Nilia $\mathrm{X}_{1}=$ 0.204 merupakan nilai tambah untuk meningkatkan minat menabung nasabah.

Gambar 4.9

Hasil Uji-t ( $\mathrm{X}_{1}$ terhadap Y)

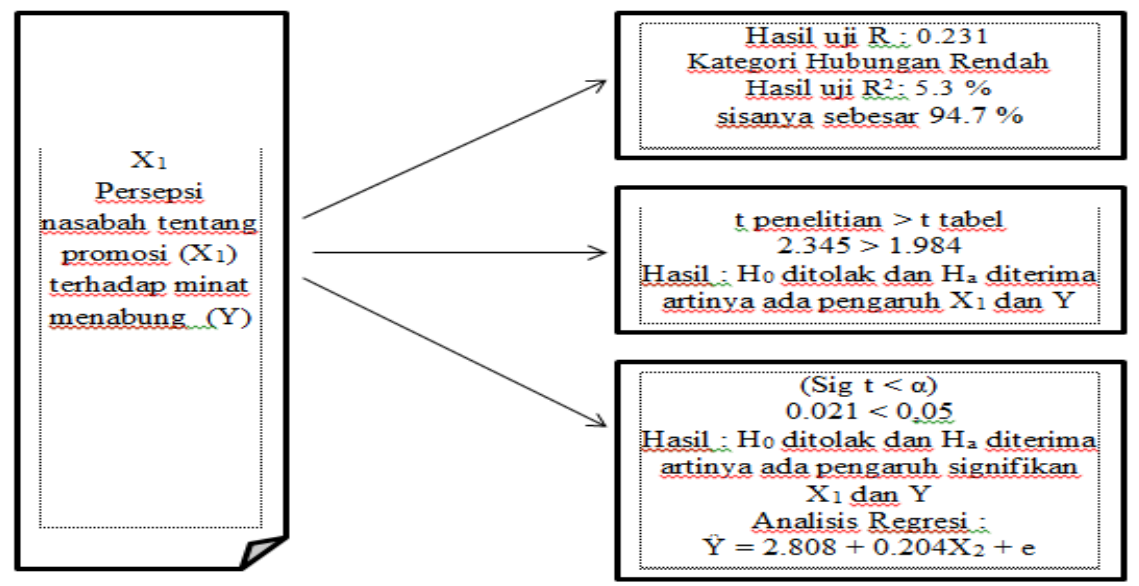

Sumber : Data diolah 2017

Berdasarkan hasil analisis diatas, bahwa angka korelasi/R $\mathrm{X}_{1}$ terhadap $\mathrm{Y}$ sebesar 0.231 menunjukkan hubungan antara variabel persepsi nasabah tentang promosi terhadap minat menabung nasabah adalah rendah. Namun hasil tersebut searah 
karena hasilnya positif. Pengaruh/Uji $\mathrm{R}^{2}$ adalah $5.3 \%$ sisanya $94.75 \%$ dipengaruhi oleh faktor lain. Uji-t untuk $\mathrm{X}_{1}$ terhadap $\mathrm{Y}$ adalah $2.345>\mathrm{t}_{\text {tabel }} 1.984$, Artinya ada pengaruh 'Persepsi nasabah tentang promosi terhadap minat menabung nasabah" dengan taraf signifikan sebesar $0.021<0.05$. Hasil analisis Regresi sebesar :

$\mathrm{X}_{1}$ terhadap $\mathrm{Y}: \hat{\mathrm{Y}}=2.808+0.204 \mathrm{X}_{2}+\mathrm{e}$.

2) Pengaruh persepsi nasabah tentang kualitas pelayanan terhadap minat menabung nasabah. $\left(X_{2}\right.$ terhadap $\left.Y\right)$

Tabel 4.13

Uji R \& $\mathrm{R}^{2},\left(\mathrm{X}_{2}\right.$ terhadap $\left.\mathrm{Y}\right)$

Model Summary

\begin{tabular}{|l|r|r|r|c|}
\hline Model & \multicolumn{1}{|c|}{$\mathrm{R}$} & $\mathrm{R}$ Square & $\begin{array}{c}\text { Adjusted R } \\
\text { Square }\end{array}$ & $\begin{array}{c}\text { Std. Error of the } \\
\text { Estimate }\end{array}$ \\
\hline 1 & $.391^{\mathrm{a}}$ & .153 & .144 & .61076 \\
\hline
\end{tabular}

a. Predictors: (Constant), Persepsi nasabah tentang kualitas pelayanan

b. Dependent Variable: Minat menabung nasabah

Sumber : Hasil Output olahan SPSS 21

Hasil uji R, uji $\mathrm{R}^{2}$ dan Uji-t adalah :

Pertama : Hasil Uji R ( $\mathrm{X}_{2}$ terhadap $\left.\mathrm{Y}\right)$, berdasarkan tabel 4.13 besarnya nilai $\mathrm{R}$ adalah 0.391, nilai tersebut untuk melihat hubungan satu variabel dengan variabel lainnya tetapi tidak menjelaskan hubungan sebab akibat. Hubungan antar variabel ditunjukkan oleh nilai koefisien korelasi sebesar 0.391 artinya hubungan antara "persepsi nasabah tentang kualitas pelayanan terhadap minat menabung' adalah rendah tapi positif. Interval koefisien korelasi $0.200-0.399=$ Kategori Hubungan Rendah (Lihat pada nilai korelasi dan kategori hubungan).

Kedua : Hasil Uji R ( $\mathrm{X}_{1}$ terhadap Y), berdasarkan tabel 4.13 diatas besarnya $\mathrm{R}$ square $\left(\mathrm{r}^{2}\right)$ adalah 0.153 Angka tersebut digunakan untuk melihat besarnya pengaruh persepsi nasabah tentang promosi terhadap minat menabung nasabah, dengan cara menghitung koefisien determinasi (KD) dengan menggunakan rumus sebagai berikut :

$\mathrm{KD}=\mathrm{r}^{2} \times 100 \%$

$\mathrm{KD}=0.153 \times 100 \%$

$\mathrm{KD}=15.3 \%$

Angka tersebut mempunyai maksud bahwa pengaruh persepsi nasabah tentang promosi terhadap minat menabung nasabah secara parsial adalah $15.3 \%$, sedangkan sisanya sebesar $84.7 \%(100 \%-15.3 \%)$ dipengaruhi oleh faktor lain.

Ketiga : Hasil Uji-t penelitian $\left(\mathrm{X}_{2}\right.$ terhadap $\left.\mathrm{Y}\right)$

Tabel 4.14

Uji-t SPSS ( $\mathrm{X}_{2}$ terhadap Y)

Coefficients $^{a}$

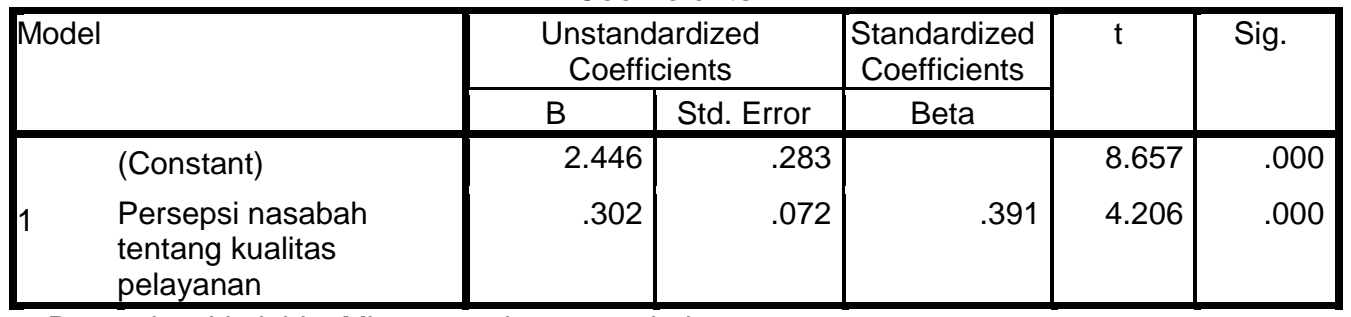

a. Dependent Variable: Minat menabung nasabah

Sumber : Hasil Output olahan SPSS 21 
Hasil Uji-t penelitian ( $\mathrm{X}_{2}$ terhadap Y), berdasarkan tabel 4.14 diatas besarnya $\mathrm{t}$ adalah 4.206. Untuk menentukan besarnya $t$ tabel adalah sebagai berikut :

1. Menghitung besarnya $t$ tabel yaitu dengan Derajat kebebasan (DK) dengan ketentuan : $\mathrm{DK}=\mathrm{n}-\mathrm{k}$, atau (jumlah sampel - variabel yang diteliti) yaitu $100-2$ $=98$. Dari ketentuan tersebut diperoleh $t$ tabel sebesar 1.984 (table critical value for the $t$ distribution).

2. Melihat penentuan Hipotesis awal yang peneliti tulis pada BAB 2 .

$\mathrm{H}_{0} \quad$ : Tidak ada pengaruh antara persepsi nasabah tentang kualitas pelayanan terhadap minat menabung nasabah.

$\mathrm{H}_{\mathrm{a}}$ : Ada pengaruh antara persepsi nasabah tentang kualita pelayanan terhadap minat menabung nasabah.

3. Menentukan kriteria uji hipotesis sebagai berikut :

Jika $\mathrm{t}_{\text {penelitian }}>\mathrm{t}$ tabel maka $\mathrm{H}_{0}$ ditolak dan $\mathrm{H}_{\mathrm{a}}$ diterima

Jika $\mathrm{t}_{\text {penelitian }}<\mathrm{t}$ tabel maha $\mathrm{H}_{0}$ diterima dan $\mathrm{H}_{\mathrm{a}}$ ditolak

Ketentuan taraf signifikansi 0.05 dengan ketentuan jika probabilitas $t$ hitung lebih kecil dari pada taraf uji penelitian $\left(\mathrm{Sig} \mathrm{t}<\alpha\right.$ ) maka $\mathrm{H}_{0}$ ditolak dan $\mathrm{H}_{\mathrm{a}}$ diterima yang memiliki arti bahwa variabel independen secara parsial memiliki pengaruh signifikan terhadap variabel dependen begitu sebaliknya jika probabilitas hitung lebih besar dari pada taraf uji penelitian (Sig $\mathrm{t}>\alpha$ ) maka $\mathrm{H}_{a}$ ditolak dan $\mathrm{H}_{0}$ diterima yang memiliki arti bahwa variabel independen secara parsial tidak signifikan terhadap variabel dependen.

4. Membuat keputusan :

Berdasarkan pada hasil perhitungan, diperoleh angka $\mathrm{t}$ penelitian sebesar $4.206>\mathrm{t}$ tabel sebesar 1.984. Sehingga $\mathrm{H}_{0}$ ditolak dan $\mathrm{H}_{\mathrm{a}}$ diterima. Artinya ada pengaruh antara pesepsi nasabah tentang promosi dengan minat menabung nasabah. Taraf signifikansi sebesar $0.000<0.05$ maka $\mathrm{H}_{0}$ ditolak dan $\mathrm{H}_{\mathrm{a}}$ diterima, arinya bahwa variabel persepsi nasabah tentang

Kualitas pelayanan secara parsial memiliki pengaruh signifikan terhadap variabel minat menabung nasabah. Hasil variabel persepsi nasabah tentang kualitas pelayanan mendapatkan nilai tertinggi dari pada variabel persepsi nasabah tentang promosi terhadap minat menabung nasabah, untuk itu kualitas pelayanan tetap harus ditingkatkan untuk memberikan kepuasan terahadap nasabah khususnya minat menabung nasabah di bank bjb syariah KCP Cikarang.

Keempat : Hasil Analisis Regresi Ganda $\mathrm{X}_{2}$ terhadap $\mathrm{Y}$

Tabel 4.15

Analisis Regresi Linier Ganda ( $\mathrm{X}_{2}$ terhadap Y) Coefficients ${ }^{\mathrm{a}}$

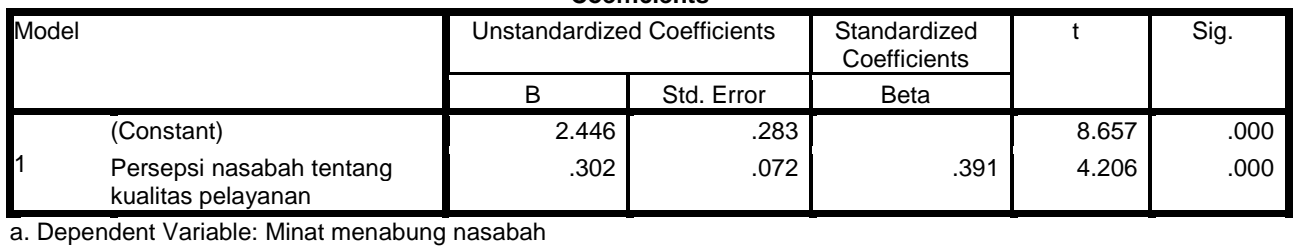

Berdasarkan analisis tabel 4.15 maka diperoleh persamaan regresi dengan nilai point sebagai berikut : $\hat{\mathrm{Y}}=2.446+0.302 \mathrm{X}_{2}+\mathrm{e}$.

Artinya bahwa : Nilai minat menabung nasabah sebesar 2.446 jika tidak ada $\mathrm{X}_{2}$. Sehingga untuk meningkatkan minat menabung tersebut perlu adanya persepsi nasabah tentang kualitas pelayanan yang baik yang diberi nilai 0.302. Intinya 
Nilia $\mathrm{X}_{2}=0.302$ merupakan nilai tambah untuk meningkatkan minat menabung nasabah.

Gambar 4.10

Hasil Uji-t $\left(\mathrm{X}_{2}\right.$ terhadap $\left.\mathrm{Y}\right)$

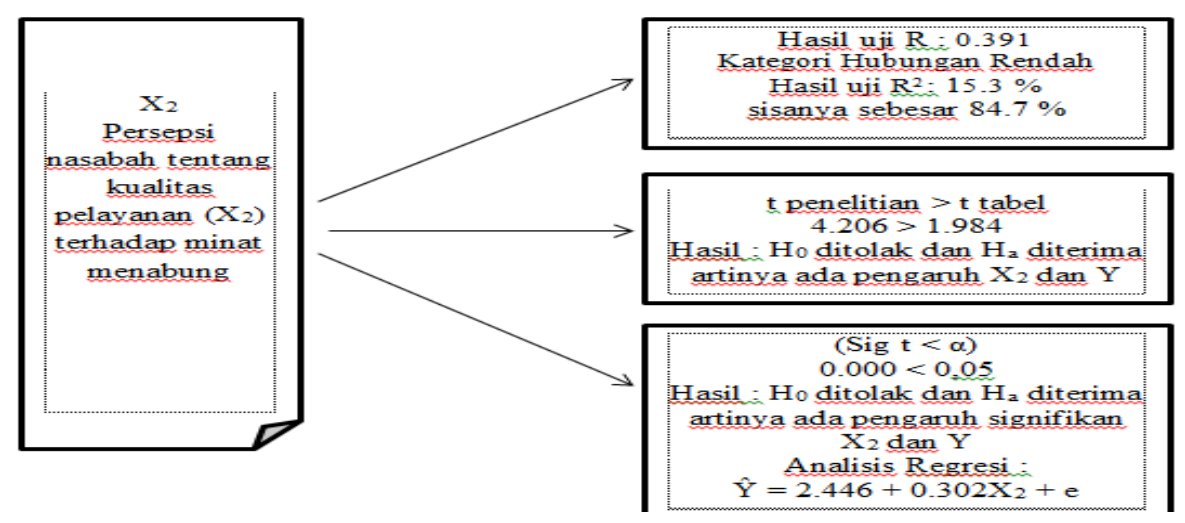

Sumber : Data diolah 2017

Berdasarkan hasil analisis diatas, bahwa angka korelasi/R $\mathrm{X}_{2}$ terhadap $\mathrm{Y}$ sebesar 0.391 menunjukkan hubungan antara variabel persepsi nasabah tentang promosi terhadap minat menabung nasabah adalah rendah. Namun hasil tersebut searah karena hasilnya positif. Pengaruh/Uji $\mathrm{R}^{2}$ adalah $15.3 \%$ sisanya $84.75 \%$ dipengaruhi oleh faktor lain. Uji $\mathrm{t}$ untuk $\mathrm{X}_{2}$ terhadap $\mathrm{Y}$ adalah $4.206>\mathrm{t}$ tabel 1.984 , Artinya ada pengaruh 'Persepsi nasabah tentang kualitas pelayanan terhadap minat menabung nasabah" dengan taraf signifikan sebesar $0.021<0.05$. Hasil analisis Regresi sebesar X terhadap $\mathrm{Y}: \hat{\mathrm{Y}}=2.446+0.302 \mathrm{X}_{2}+\mathrm{e}$.

\section{b. Pengaruh persepsi nasabah tentang promosi dan kualitas pelayanan secara simultan/gabungan terhadap minat menabung nasabah.}

Untuk melihat besarnya pengaruh persepsi nasabah tentang promosi dan kualitas pelayanan secara gabungan/simultan terhadap minat menabung nasabah, digunakan Uji-F.

Tabel 4.16

Uji R \& $\mathrm{R}^{2}$, ( $\mathrm{X}_{1}$ dan $\mathrm{X}_{2}$ terhadap $\left.\mathrm{Y}\right)$ Model Summaryb

\begin{tabular}{|l|r|r|r|c|}
\hline Model & \multicolumn{1}{|c|}{$\mathrm{R}$} & $\mathrm{R}$ Square & \multicolumn{1}{c|}{$\begin{array}{c}\text { Adjusted R } \\
\text { Square }\end{array}$} & $\begin{array}{c}\text { Std. Error of the } \\
\text { Estimate }\end{array}$ \\
\hline 1 & $.468^{\mathrm{a}}$ & .219 & .203 & .58943 \\
\hline
\end{tabular}

a. Predictors: (Constant), Persepsi nasabah tentang kualitas

pelayanan, Persepsi nasabah tentang promosi

b. Dependent Variable: Minat menabung nasabah

Sumber : Hasil Output olahan SPSS 21

Hasil uji R, uji $\mathrm{R}^{2}$ dan Uji-F adalah :

Pertama : Hasil Uji $\mathrm{R}\left(\mathrm{X}_{1}\right.$ dan $\mathrm{X}_{2}$ terhadap $\left.\mathrm{Y}\right)$ : berdasarkan tabel 4.16 besarnya nilai $\mathrm{R}$ adalah 0.468 , nilai tersebut untuk melihat hubungan satu variabel dengan variabel lainnya tetapi tidak menjelaskan hubungan sebab akibat. Hubungan antar variabel ditunjukkan oleh nilai koefisien korelasi sebesar 0.468 artinya hubungan antara "persepsi nasabah tentang promosi dan kualitas pelayanan terhadap minat menabung" adalah sedang karena masuk pada interval koefisien korelasi $0.4000-0.599=$ Kategori Hubungan Sedang (Lihat pada nilai korelasi dan kategori hubungan). 
Kedua : Hasil Uji R Square ( $\mathrm{X}_{1}$ dan $\mathrm{X}_{2}$ terhadap $\mathrm{Y}$ ), berdasarkan tabel 4.16 diatas besarnya $\mathrm{R}$ square $\left(\mathrm{r}^{2}\right)$ adalah 0.219 Angka tersebut digunakan untuk melihat besarnya pengaruh persepsi nasabah tentang promosi dan kualitas pelayanan terhadap minat menabung nasabah, dengan cara menghitung koefisien determinasi (KD) dengan menggunakan rumus sebagai berikut :

$\mathrm{KD}=\mathrm{r}^{2} \times 100 \%$

$\mathrm{KD}=0.219 \times 100 \%$

$\mathrm{KD}=21.9 \%$

Angka tersebut mempunyai maksud bahwa pengaruh persepsi nasabah tentang promosi dan kualitas pelayanan terhadap minat menabung nasabah secara gabungan adalah $21.9 \%$, sedangkan sisanya sebesar $78.1 \%(100 \%-21.9 \%)$ dipengaruhi oleh faktor lain. Dengan kata lain, variabilitas minat menabung nasabah dapat diterangkan dengan menggunakan variabel persepsi nasabah tentang promosi dan kualitas pelayanan sebesar $21.9 \%$, sementara pengaruh sebesar $78.1 \%$ disebabkan oleh variabel-variabel lain di luar model ini.

Ketiga : Hasil Uji-F penelitian ( $\mathrm{X}_{1}$ dan $\mathrm{X}_{2}$ terhadap $\mathrm{Y}$ )

Tabel 4.17

Hasil Uji-F SPSS ( $\mathrm{X}_{1}$ dan $\mathrm{X}_{2}$ terhadap $\left.\mathrm{Y}\right)$

ANOVA $^{\mathrm{a}}$

\begin{tabular}{|rl|r|r|r|r|r|}
\hline Model & & Sum of Squares & \multicolumn{1}{|c|}{$\mathrm{df}$} & Mean Square & $\mathrm{F}$ & Sig. \\
\hline \multirow{4}{*}{1} & Regression & 9.456 & 2 & 4.728 & 13.608 & $.000^{\mathrm{b}}$ \\
& Residual & 33.701 & 97 & .347 & & \\
& Total & 43.156 & 99 & & & \\
\hline
\end{tabular}

a. Dependent Variable: Minat menabung nasabah

b. Predictors: (Constant), Persepsi nasabah tentang kualitas pelayanan, Persepsi nasabah tentang promosi

Sumber : Hasil Output olahan SPSS 21

Dari tabel 4.17 hasil Uji-F penelitian 'Pengaruh persepsi nasabah tentang promosi dan kualitas pelayanan terhadap minat menabung nasabah" adalah sebesar 13.608. Untuk menentukan besarnya $F_{\text {tabel }}$ adalah sebagai berikut :

1. Menghitung besarnya $F$ tabel yaitu dengan Derajat kebebasan (DK) dengan ketentuan numerator : $\mathrm{df}(\mathrm{n} 1)=\mathrm{k}-1$ (jumlah variabel -1 ) atau $3-1=2$, dan denumerator : df $(\mathrm{n} 2)=\mathrm{n}-\mathrm{k}($ jumlah sampel -3$)$ atau $100-3=97$. Jika pengujian dilakukan pada $\alpha=5 \%$, maka nilai $\mathrm{F}$ tabel nya adalah 3,09 (table critical values for the F Dist. $(\alpha=0.05)$.

2. Melihat penentuan Hipotesis awal yang peneliti tulis pada BAB 2.

$\mathrm{H}_{0}$ : Tidak ada pengaruh persepsi nasabah tentang promosi dan

kualitas pelayanan terhadap minat menabung.

$\mathrm{H}_{\mathrm{a}}$ : Ada pengaruh persepsi nasabah tentang promosi dan kualitas pelayanan terhadap minat menabung.

3. Menentukan kriteria uji hipotesis sebagai berikut :

Jika $\mathrm{F}_{\text {penelitian }}>\mathrm{F}$ tabel maka $\mathrm{H}_{0}$ ditolak dan $\mathrm{H}_{\mathrm{a}}$ diterima

Jika $\mathrm{F}$ Penelitian $<\mathrm{F}$ tabel maka $\mathrm{H}_{0}$ diterima dan $\mathrm{H}_{\mathrm{a}}$ ditolak

Ketentuan taraf signifikansi 0,05 dengan ketentuan jika probabilitas $\mathrm{F}$ hitung lebih kecil dari pada taraf uji penelitian $(\operatorname{Sig} \mathrm{F}<\alpha)$ maka $\mathrm{H}_{0}$ ditolak dan $\mathrm{H}_{\mathrm{a}}$ diterima yang memiliki arti bahwa variabel independen secara simultan memiliki pengaruh signifikan terhadap variabel dependen begitu sebaliknya jika probabilitas hitung lebih besar dari pada taraf uji penelitian (Sig F $>\alpha$ ) maka $\mathrm{H}_{\mathrm{a}}$ 
ditolak dan $\mathrm{H}_{0}$ diterima yang memiliki arti bahwa variabel independen secara simultan tidak signifikan terhadap variabel dependen.

4. Membuat keputusan :

Berdasarkan pada hasil perhitungan, diperoleh angka $\mathrm{F}$ penelitian sebesar $13.608>$ $\mathrm{F}$ tabel sebesar 3.09 sehingga $\mathrm{H}_{0}$ ditolak dan $\mathrm{H}_{\mathrm{a}}$ diterima. Artinya ada pengaruh antara pesepsi nasabah tentang promosi dan kualitas pelayanan terhadap minat menabung nasabah. Taraf signifikansi sebesar $0.000<0.05$ maka $\mathrm{H}_{0}$ ditolak dan $\mathrm{H}_{\mathrm{a}}$ diterima, arinya bahwa variabel persepsi nasabah tentang kualitas pelayanan secara simultan memiliki pengaruh signifikan terhadap variabel minat menabung nasabah.

Keempat : Hasil Analisis Regresi Ganda ( $\mathrm{X}_{1}$ dan $\mathrm{X}_{2}$ terhadap $\left.\mathrm{Y}\right)$

Tabel 4.18

Analisis Regresi Linier Ganda ( $\mathrm{X}_{1}$ dan $\mathrm{X}_{2}$ terhadap $\left.\mathrm{Y}\right)$

Coefficients $^{\mathrm{a}}$

\begin{tabular}{|c|c|c|c|c|c|c|}
\hline \multirow[t]{2}{*}{ Mod } & & \multicolumn{2}{|c|}{ Unstandardized Coefficients } & \multirow{2}{*}{$\begin{array}{c}\text { Standardized } \\
\text { Coefficients } \\
\text { Beta }\end{array}$} & \multirow[t]{2}{*}{$\mathrm{t}$} & \multirow[t]{2}{*}{ Sig. } \\
\hline & & B & Std. Error & & & \\
\hline \multirow{3}{*}{1} & (Constant) & 1.502 & .427 & & 3.514 & .001 \\
\hline & $\begin{array}{l}\text { Persepsi nasabah tentang } \\
\text { promosi }\end{array}$ & .228 & .080 & .258 & 2.867 & .005 \\
\hline & $\begin{array}{l}\text { Persepsi nasabah tentang } \\
\text { kualitas pelayanan }\end{array}$ & .316 & .069 & .408 & 4.540 & .000 \\
\hline
\end{tabular}

a. Dependent Variable: Minat menabung nasabah

Sumber : Hasil Output olahan SPSS 21

Berdasarkan analisis tabel 4.18 maka diperoleh persamaan regresi dengan nilai point sebagai berikut : $\hat{\mathrm{Y}}=1.502+0,228 \mathrm{X}_{1}+0,316 \mathrm{X}_{2}+\mathrm{e}$.

Artinya bahwa : Nilai minat menabung nasabah sebesar 1.502 jika tidak ada $\mathrm{X}_{1}$ dan $\mathrm{X}_{2}$. Sehingga untuk meningkatkan minat menabung tersebut perlu adanya persepsi nasabah tentang promosi yang baik yang diberi nilai 0,228 dan persepsi nasabah tentang kualitas pelayanan yang baik yang diberi nilai 0,316 . Nilai $\mathrm{X}_{1}$ dan $\mathrm{X}_{2}(0,228$ dan 0,316$)$ merupakan nilai tambah untuk meningkatkan minat menabung nasabah.

Gambar 4.11

Hasil Uji-F ( $\mathrm{X}_{1}$ dan $\mathrm{X}_{2}$ terhadap $\left.\mathrm{Y}\right)$

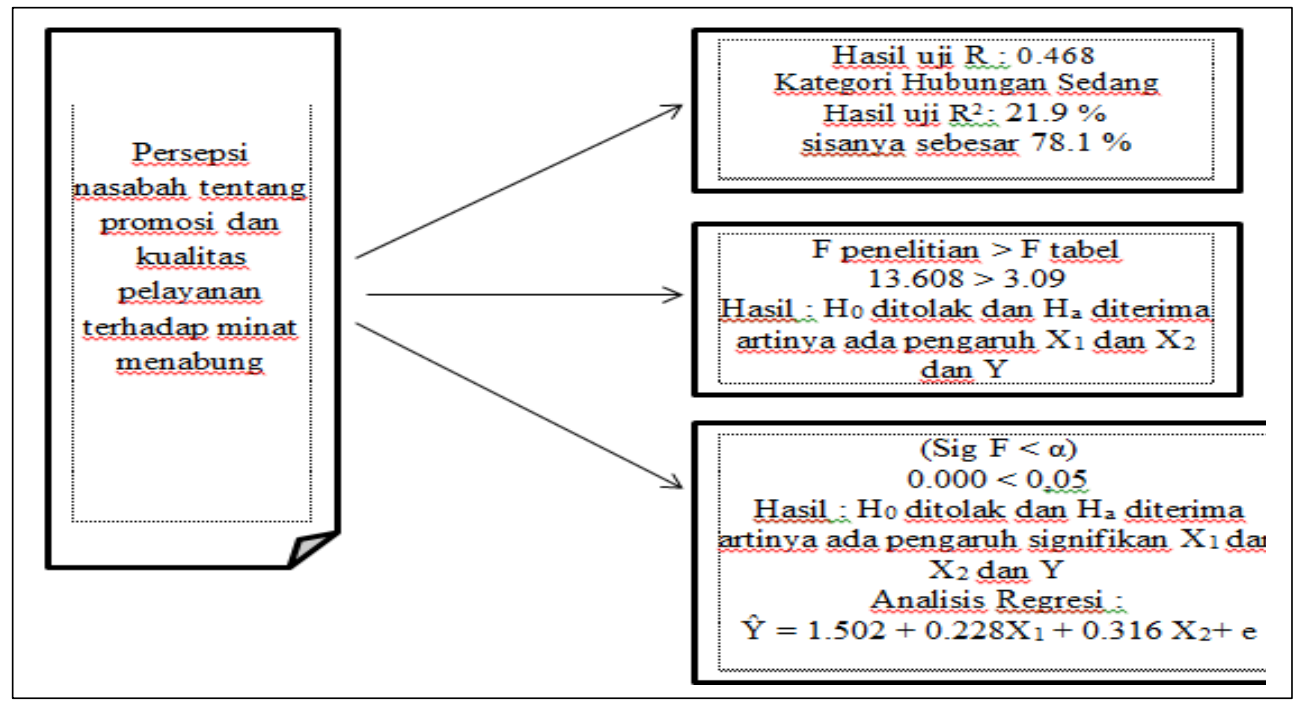


Sumber : Data diolah 2017

\section{Hasil Uji Hipotesis}

Hsil Uji-t dan Uji-F dan besarnya pada signifikansi 5\% adalah sebagai berikut:

Tabel 4.19

Pengujian Hipotesis Secara Parsial dan Simultan

\begin{tabular}{|c|l|c|c|}
\hline No & \multicolumn{1}{|c|}{ Hipotesis Alternatif (Ha) } & Nilai & Status \\
\hline 1. & $\begin{array}{l}\text { Secara parsial variabel Persepsi nasabah tentang } \\
\text { promosi berpengaruh secara signifikan terhadap minat } \\
\text { menabung nasabah. }\end{array}$ & $\begin{array}{c}\mathrm{t}=2.345 \\
\mathrm{Sig} \mathrm{t}=0.021 \\
\mathrm{t} \text { tabel }=1.984\end{array}$ & $\begin{array}{c}\mathrm{H}_{0} \text { ditolak dan } \\
\mathrm{H}_{\mathrm{a}} \text { diterima }\end{array}$ \\
\hline 2. & $\begin{array}{l}\text { Secara parsial variabel Persepsi nasabah tentang } \\
\text { kualitas pelayanan berpengaruh secara signifikan } \\
\text { terhadap minat menabung nasabah. }\end{array}$ & $\begin{array}{c}\mathrm{t}=4.206 \\
\mathrm{Sig} \mathrm{t}=0.000 \\
\mathrm{t}\end{array}$ & $\begin{array}{c}\mathrm{H}_{0} \text { ditolak dan } \\
\mathrm{H}_{\mathrm{a}} \text { diterima }\end{array}$ \\
\hline 3. & $\begin{array}{l}\text { Secara simultan variabel Pengaruh persepsi nasabah } \\
\text { tentang promosi dan kualitas pelayanan terhadap } \\
\text { minat menabung nasabah berpengaruh secara } \\
\text { signifikan terhadap minat menabung nasabah. }\end{array}$ & $\begin{array}{c}\mathrm{F}=13.608 \\
\mathrm{Sig}=0.000\end{array}$ & $\mathrm{~F}_{\text {tabel }}=3.09$ \\
\hline
\end{tabular}

Sumber: Data diolah 2017

* signifikan pada level $5 \%$

\section{Pembahasan Hasil Penelitian}

Dari hasil analisis maka pembahasan tentang hasil penelitian ini adalah sebagai berikut :

1. Pengaruh Persepsi Nasabah tentang Promosi terhadap Minat Menabung Nasabah. Berdasarkan hasil analisis bahwa angka korelasi $\mathrm{R} \mathrm{X}_{1}$ terhadap $\mathrm{Y}$ sebesar 0.231 men unjukkan hubungan antara variabel persepsi nasabah tentang promosi terhadap minat menabung nasabah adalah rendah. Namun hasil tersebut searah karena hasilnya positif. Pengaruh atau Uji $\mathrm{R}^{2}$ adalah $5.3 \%$ sisanya 94.75\% dipengaruhi oleh faktor lain. Uji-t untuk $\mathrm{X}_{1}$ terhadap $\mathrm{Y}$ adalah $2.345>\mathrm{t}$ tabel 1.984, Artinya ada pengaruh 'Persepsi nasabah tentang promosi terhadap minat menabung nasabah" dengan taraf signifikan sebesar $0.021<0.05$. Hasil analisis regresi $\mathrm{X}_{1}$ terhadap $\mathrm{Y}$ sebesar $: \hat{\mathrm{Y}}=2.808+0.204 \mathrm{X}_{2}+\mathrm{e}$.

2. Pengaruh Persepsi Nasabah tentang Kualitas Pelayanan terhadap Minat Menabung Nasabah. Berdasarkan hasil analisis bahwa angka korelasi $\mathrm{R} \quad \mathrm{X}_{2}$ terhadap Y sebesar 0.391 menunjukkan hubungan antara variabel persepsi nasabah tentang promosi terhadap minat menabung nasabah adalah rendah. Namun hasil tersebut searah karena hasilnya positif. Pengaruh atau $\mathrm{Uji}^{2} \mathrm{R}^{2}$ adalah $15.3 \%$ sisanya $84.75 \%$ dipengaruhi oleh faktor lain. Uji-t untuk $X_{2}$ terhadap $Y$ adalah $4.206>\mathrm{t}$ tabel 1.984, Artinya ada pengaruh 'Persepsi nasabah tentang kualitas pelayanan terhadap minat menabung nasabah" dengan taraf signifikan sebesar $0.000<0.05$. Hasil analisis Regresi sebesar X terhadap $\mathrm{Y}: \hat{\mathrm{Y}}=2.446+$ $0.302 \mathrm{X}_{2}+\mathrm{e}$.

2. Pengaruh Persepsi Nasabah tentang Promosi dan Kualitas Pelayanan terhadap Minat Menabung Nasabah.Berdasarkan hasil analisis bahwa angka korelasi $\mathrm{R} \mathrm{X}_{1}$ dan $\mathrm{X}_{2}$ terhadap $\mathrm{Y}$ sebesar 0.468 menunjukkan hubungan antara variabel persepsi nasabah tentang promosi terhadap minat menabung nasabah adalah sedang dan searah karena hasilnya positif. Pengaruh atau $\mathrm{Uji}^{2}$ adalah $21.9 \%$ sisanya $78.1 \%$ dipengaruhi oleh faktor lain. Uji-F untuk $\mathrm{X}_{1}$ dan $\mathrm{X}_{2}$ terhadap $\mathrm{Y}$ adalah $13.608>\mathrm{F}$ tabel 3.09, Artinya ada pengaruh 'Persepsi nasabah tentang promosi dan kualitas pelayanan terhadap minat menabung nasabah" dengan taraf 
signifikan sebesar $0.000<0.05$. Hasil analisis regresi $\mathrm{X}_{1}$ dan $\mathrm{X}_{2}$ terhadap $\mathrm{Y}$ sebesar :

$\hat{Y}=1.502+0.228 \mathrm{X}_{1}+0.316 \mathrm{X}_{2}+\mathrm{e}$.

\section{TEMUAN}

Berdasarkan hasil analisis yang telah dilakukan, maka dapat ditarik beberapa kesimpulan sebagai berikut :

1. Pengaruh Persepsi Nasabah tentang Promosi terhadap Minat Menabung Nasabah. Berdasarkan hasil analisis bahwa angka korelasi $\mathrm{R} \quad \mathrm{X}_{1}$ terhadap Y sebesar 0.231 menunjukkan hubungan antara variabel persepsi nasabah tentang promosi terhadap minat menabung nasabah adalah rendah. Namun hasil tersebut searah karena hasilnya positif. Pengaruh atau Uji $\mathrm{R}^{2}$ adalah $5.3 \%$ sisanya $94.75 \%$ dipengaruhi oleh faktor lain. Uji-t untuk $\mathrm{X}_{1}$ terhadap $\mathrm{Y}$ adalah $2.345>\mathrm{t}$ tabel 1.984, Artinya ada pengaruh 'Persepsi nasabah tentang promosi terhadap minat menabung nasabah" dengan taraf signifikan sebesar $0.021<0.05$. Hasil analisis regresi $\mathrm{X}_{1}$ terhadap $\mathrm{Y}$ sebesar : $\hat{\mathrm{Y}}=2.808+0.204 \mathrm{X}_{1}+\mathrm{e}$.

2. Pengaruh Persepsi Nasabah tentang Kualitas Pelayanan terhadap Minat Menabung Nasabah. Berdasarkan hasil analisis bahwa angka korelasi R $\mathrm{X}_{2}$ terhadap $\mathrm{Y}$ sebesar 0.391 menunjukkan hubungan antara variabel persepsi nasabah tentang promosi terhadap minat menabung nasabah adalah rendah. Namun hasil tersebut searah karena hasilnya positif. Pengaruh atau Uji $\mathrm{R}^{2}$ adalah $15.3 \%$ sisanya $84.75 \%$ dipengaruhi oleh faktor lain. Uji-t untuk $\mathrm{X}_{2}$ terhadap Y adalah $4.206>\mathrm{t}$ tabel 1.984 , Artinya ada pengaruh 'Persepsi nasabah tentang kualitas pelayanan terhadap minat menabung nasabah" dengan taraf signifikan sebesar $0.021<0.05$. Hasil analisis Regresi sebesar X terhadap $\mathrm{Y}: \hat{\mathrm{Y}}=2.446+0.302 \mathrm{X}_{2}+\mathrm{e}$.

3. Pengaruh Persepsi Nasabah tentang Promosi dan Kualitas Pelayanan terhadap Minat Menabung Nasabah. Berdasarkan hasil analisis bahwa angka korelasi $\mathrm{R} \quad \mathrm{X}_{1}$ dan $\mathrm{X}_{2}$ terhadap $\mathrm{Y}$ sebesar 0.468 menunjukkan hubungan antara variabel persepsi nasabah tentang promosi terhadap minat menabung nasabah adalah sedang dan searah karena hasilnya positif. Pengaruh atau Uji $\mathrm{R}^{2}$ adalah $21.9 \%$ sisanya $78.1 \%$ dipengaruhi oleh faktor lain. Uji-F untuk $\mathrm{X}_{1}$ dan $\mathrm{X}_{2}$ terhadap $\mathrm{Y}$ adalah $13.608>\mathrm{F}_{\text {tabel }} 3.09$, Artinya ada pengaruh 'Persepsi nasabah tentang promosi dan kualitas pelayanan terhadap minat menabung nasabah' dengan taraf signifikan sebesar $0.000<0.05$. Hasil analisis regresi $\mathrm{X}_{1}$ dan $\mathrm{X}_{2}$ terhadap $\mathrm{Y}$ sebesar : $\hat{\mathrm{Y}}=1.502+0.228 \mathrm{X}_{1}+0.316 \mathrm{X}_{2}+\mathrm{e}$.

4. Pengaruh variabel persepsi nasabah tentang kualitas pelayanan memiliki nilai terbesar yaitu nilai Uji-t $\mathrm{X}_{2}$ sebesar $4.206>\mathrm{t}$ tabel 1.984 sedangkan variabel persepsi nasabah tentang promosi memiliki nilai Uji-t $\mathrm{X}_{1}$ sebesar $2.345>\mathrm{t}$ tabel 1.984 terhadap minat menabung. Hal ini dapat disimpulkan bahwa minat menabung nasabah dipengaruhi oleh variabel yang pertama adalah persepsi nasabah tentang kualitas pelayanan dan yang kedua adalah persepsi nasabah tentang promosi.

\section{Saran}

1. Penelitian dilakukan dengan menggunakan dua variabel saja, yaitu persepsi nasabah tentang promosi dan persepsi nasabah tentang kualitas 
pelayanan. Saran agar penelitian selanjutnya ditambah untuk jumlah variabelnya sehingga jawaban dari responden bervariasi, hasil lebih valid dan signifikan.

2. Hanya menggunakan 100 orang responden dikarenakan kebijakan dari bank bjb syariah untuk tidak terlalu memberikan jumlah kuesioner berlebih kepada para nasabah, Saran agar penelitian selanjutnya agar ditambah jumlah responden lebih dari 100.

3. Untuk bank bjb syariah Kantor Cabang Pembantu Cikarang, diharapkan tetap meningkatkan kualitas pelayan dan tingkat promosi untuk para nasabah. Persepsi nasabah yang baik akan memberikan dampak keuntungan bagi perusahaan. Promosi dan Kualitas pelayanan menjadi penting karena akan berdampak pada kemajuan perusahaan khususnya untuk menarik minat menabung nasabah.

\section{REFERENSI}

Arikunto, Suharsimi, Prosedur Penelitian : Suatu Pendekatan Praktek, Jakarta: PT. Rineka Cipta, 2002.

Bin Badri Muhammad Arifin , Riba \& Tinjauan Kritis Perbankan Syariah, Cileungi-Bogor: CV. Darul Ilmi Publishing, 2012.

Kasmir, Dasar-dasar Perbankan, Jakarta: PT. Raja Grafindo Persada, 2012.

Kamsi, Pokok-pokok Pengetahuan Hukum Dagang Indonesia, Jakarta: Sinar Grafika, 2002.

Kotler,Philip dan Garry Amstrong, Prinsip-prinsip Pemasaran edisi 12, Jakarta: Erlangga, 2008.

Mulyanto Heru, Anna Wulandari, Penelitian Metode \& Analisis, Semarang: CV Agung Semarang, 2010.

Moeliono Anton, Kamus Besar Bahasa Indonesia, Jakarta: Balai Pustaka, 1999.

Rangkuti, Freddy, Customer Service Satisfaction \& Call Center, Jakarta: PT. Gramedia Pustaka Utama, 2013.

Sanusi, A, Metodologi Penelitian Bisnis, Jakarta : Penerbit Salemba Empat, 2011

Siswanto, Pengantar Manajemen, Jakarta : PT.Bumi Aksara, 2005

Subagyo, Ahmad, Marketing in Business, Jakarta: Mitra Wacana Media, 2010.

Sugiyono, Metode Penelitian Bisnis, Bandung: CV. Alfabeta, 2007.

Sustina, Perilaku Konsumen Dan Komunikasi Pemasaran, Bandung: PT. Remaja Rosdakarya, 2003.

INTERNET

Ridwan, Kualitas Pelayanan Dalam Islam, [Online], http://ridwan202.wordpress.com/2013/02/11/kualitas-pelayanan-dalamislam, Februari 2013.

http://www.konsistensi.com/2014/08/uji-normalitas-grafik-histogram-plot.html.

Diakses tanggal 7 Agustus 207.

www.junaidichaniago.wordpress.com

Alamsyah, Halim, Perkembangan dan Prospek Perbankan Syariah Indonesia Tantangan dalam Menyongsong MEA 2015, Jurnal Ikatan Ahli Ekonomi Islam, April 2012. 
Ariani, Dian, Persepsi Masyarakat Umum Terhadap Bank Syariah di Medan, Tesis Pasca Sarjana, Universitas Sumatera Utara, Medan: tidak diterbitkan, 2007.

Astuti,Tri, Pengaruh Persepsi Nasabah Tentang Tingkat Suku Bunga, Promosi Dan Kualitas Pelayanan Terhadap Minat Menabung Nasabah (Studi Kasus Pada BRI Cabang Sleman, Skripsi pada Universitas Negeri Yogyakarta, Yogyakarta: tidak diterbitkan, 2013.

Basuki, Aris, Analisis Marketing Mix Terhadap Kepuasan Konsumen dengan Keputusan Pembelian Sebagai Variabel Intervening dalam Membeli Notebook pada PT. Surya Wincom, Jurnal Skripsi, Universitas Katolik Darma Cendika, Surabaya: tidak diterbitkan, 2015.

Rakhmah, Sivia Miftakhur, Pengaruh Persepsi Mahasiswa tentang Bank Syariah terhadap Minat Menabung di Perbankan Syariah, Jurnal pada Universitas Jember: tidak diterbitkan, 2012.

Rahmaita, Pengaruh Persepsi tentang Bank Syariah terhadap Minat Menggunakan Produk di BNI Syariah Semarang, Jurnal pada STAIN kudus, Jawa Tengah: tidak diterbitkan, 2014.

Sulistyorini, Dian, Pengaruh Kinerja Pelayanan Terhadap Kepuasan Nasabah, Jurnal pada Universitas Diponegoro, Semarang: tidak diterbitkan, 2013.

Suparno, Persepsi Mahasiswa Fakultas Ekonomi Universitas Syiah Kuala Terhadap Perbankan Syariah Sebagai Lembaga Keuangan syariah , Jurnal pada Universitas Kuala, Aceh: tidak diterbitkan, 2009. 